\title{
The Corticosteroid Receptor Hypothesis of Depression
}

\author{
Florian Holsboer, M.D., Ph.D.
}

\begin{abstract}
Signs and symptoms that are characteristic for depression include changes in the setpoint of the hypothalamicpituitary-adrenocortical (HPA) system, which in the majority of these patients result in altered regulation of corticotropin (ACTH) and cortisol secretory activity. More refined analysis of the HPA system revealed that corticosteroid receptor (CR) signaling is impaired in major depression, resulting among other changes, in increased production and secretion of corticotropin-releasing hormone ( $C R H$, also frequently abbreviated $C R F)$ in various brain regions postulated to be involved in the causality of depression. This article summarizes the clinical and preclinical data, supporting the concept that impaired $C R$
\end{abstract}

signaling is a key mechanism in the pathogenesis of depression. Mouse genetics, allowing for selective inactivation of genes relevant for HPA regulation and molecular pharmacology, dissecting the intracellular cascade of $C R$ signaling, are the most promising future research fields, suited for identifying genes predisposing to depression. Focusing on these two research lines may also allow to gain insight into understanding how current antidepressants work and further, how more specific targets for future antidepressant drugs can be identified.

[Neuropsychopharmacology 23:477-501, 2000] (c) 2000 American College of Neuropsychopharmacology. Published by Elsevier Science Inc.
KEY WORDS: Corticosteriod receptors; CRH; HPA; Stress; Depression; Antidepressants

\section{FUNCTIONAL IMPAIRMENT OF CENTRAL CORTICOSTEROID RECEPTORS}

\section{Clinical Evidence}

Until now, the serendipitous discovery of antidepressants in the 1950s has profoundly inspired hypotheses of the pathogenesis of depression. The well-known pharmacological effects of antidepressants on presynaptic uptake transporters and degradating enzymes

From the Max Planck Institute of Psychiatry, Munich, Germany.

Address correspondence to: Florian Holsboer, M.D., Ph.D., Max Planck Institute of Psychiatry, Kraepelinstr. 2-10, D-80804 Munich, Germany.

Received February 28, 2000; revised June 22, 2000; accepted June 23,2000 . (i.e., MAO) of serotonin and norepinephrine has focused research on causality and treatment of depression on the metabolism of functional biogenic amines and the capacity of their respective receptors to alter intracellular signaling pathways that ultimately induce changes in gene activity. Elevated circulating levels of stress hormones among depressives were recognized even before antidepressants were discovered, but these changes were seen as epiphenomena, reflecting the stressful experience of depression, although M. Bleuler (1919) already demonstrated that hormones have diverse psychotropic effects and suggested hormone treatments as potential antidepressants. A vast amount of evidence has accumulated, that reject the view that altered stress hormone secretions in depression are epiphenomenal.

During the past decade, several research groups formulated a hypothesis relating aberrant stress hormone dysregulation to causality of depression and submitted that antidepressants may act through normalisation of these HPA changes (review: Holsboer and Barden 
1996). This hypothesis was derived from the following clinical observations in depressives: 1) the number of ACTH and cortisol secretory pulses is increased which is also reflected in elevated urinary cortisol production rates (Rubin et al. 1987); 2) levels of CRH in the CSF are elevated (Nemeroff et al. 1984); 3) the number of CRH secreting neurons in limbic brain regions is increased (Raadsheer et al. 1994); and 4) the number of CRH binding sites in the frontal cortex is reduced secondary to increased CRH concentration (Nemeroff et al. 1988). These studies were complemented by many neuroendocrine function tests including the suppressibility of ACTH and corticosteroids by the synthetic glucocorticoid dexamethasone (dexamethasone suppression test, DST). The DST showed that a high proportion of patients with various affective disorders have elevated cortisol levels (Carroll 1982), thus escaping the suppressive effect of dexamethasone. After CRH was discovered and characterized by Vale and coworkers (1981) initial studies employing ovine or human CRH in depressives showed that the ACTH response after injection of this neuropeptide was decreased, suggesting desensitized pituitary CRH receptors due to homologous downregulation by hypersecreted CRH (Gold et al. 1986; Holsboer et al. 1986).

The most sensitive neuroendocrine function test to detect HPA dysregulation combines the DST and the CRH stimulation test (dex/CRH test) (von Bardeleben and Holsboer 1989, 1991; Heuser et al. 1994; Rybakowski and Twardowska 1999). In this test, patients are pretreated with a single low dose $(1.5 \mathrm{mg})$ of dexamethasone at 23:00 $\mathrm{h}$ and receive intravenously $100 \mu \mathrm{g} \mathrm{CRH}$ at 15:00 h the following day. The amount of ACTH and cortisol subsequently released is much higher among depressives. In fact, Heuser and coworkers (1994) concluded from their studies that the sensitivity of this test (i.e., likelihood to differentiate between normal and pathological states) is above $80 \%$, depending on age and gender. Whereas CRH-elicited ACTH response is blunted in depressives, dexamethasone pretreatment produces the opposite effect and paradoxically enhances ACTH release following CRH. Similarly, CRH-induced cortisol release is much higher in dexamethasone-pretreated patients than following a challenge with CRH alone. The interpretation of the above findings is as follows: dexamethasone, due to its low binding to corticosteroid binding globulin and its decreased access to the brain (Meijer et al. 1998), acts primarily at the pituitary to suppress ACTH. The subsequent decrease of cortisol and the failure of dexamethasone to compensate for the decreased cortisol levels in the nervous tissue creates a situation that is sensed by central regulatory elements of the HPA system as a partial and transient adrenalectomy. In response to this situation, the secretion of central neuropeptides which are capable of activating ACTH secretion-mainly $\mathrm{CRH}$ and vasopressin-is increased. Vasopressin is known to synergize with $\mathrm{CRH}$, overriding dexamethasone suppression at hu- man corticotrophs: When vasopressin is infused at a low rate into dexamethasone pretreated controls, concurrent infusion with $\mathrm{CRH}$ induces an ACTH and cortisol response which is similar to the hormone secretory profile of depressives receiving the combined dex/CRH-test but without simultaneous vasopressin treatment (von Bardeleben et al. 1985). This finding led us to postulate that hypothalamic vasopressin is increased in depressives (von Bardeleben and Holsboer 1989). A more recent study by Purba and coworkers (1996) reporting increased numbers of vasopressin-expressing neurons in the parvocellular part of the hypothalamic paraventricular nucleus of depressives ultimately confirmed this view.

All three tests (DST, CRH test, and dex/CRH test) have been frequently administered to depressed patients by several research groups. Serial DSTs during a variety of antidepressant drug treatment revealed that whenever cortisol suppression was inappropriate, i.e., above a certain threshold, normalization of the neuroendocrine dysregulation was necessary for clinical remission to become manifest. In addition, if post-dexamethasone plasma cortisol levels increased over time or remained elevated the likelihood for an unfavorable clinical course or nonresponse to treatment was high (Holsboer et al. 1982; Greden et al. 1983).

Blunted ACTH response to CRH and the normalization of elevated CRH in the CSF after antidepressantinduced clinical remission has also been reported; these findings confirm a close association between HPA dysregulation and depressive psychopathology (de Bellis et al. 1993). The combined dex/CRH test proved particularly useful as a predictor of increased risk for relapse (Holsboer et al. 1987; Holsboer-Trachsler et al. 1994; Heuser et al. 1996; Zobel et al. 1999).

In those patients where the neuroendocrine abnormality persisted, the risk of relapse or resistance to treatment was much higher. Together, all studies reported so far indicate that reinstatement of a "normal" HPA setpoint is an important prerequisite for clinical improvement and furthermore, if HPA abnormalities persist or become more pronounced during drug treatment the respective individual is at increased risk for relapse.

A study that administered different doses of dexamethasone prior to CRH showed that ACTH and cortisol suppression occurs at higher dexamethasone dosages in the depressives than in matched controls. This shift of the dose response curve to higher dexamethasone dosages corroborates the view that negative feedback mechanisms through glucocorticoid receptors (GR), to which dexamethasone binds, are impaired in depressives (Modell et al. 1997).

The consequences of impaired regulation of cortisol secretion are manifold, ranging from untoward effects in peripheral tissues (e.g., osteoporosis) to changes in the central nervous system. The latter are believed to comprise effects on morphology as well as on cognitive 
function. Studies by Sheline et al. $(1996,1998,1999)$ and Bremner et al. (2000) suggested that recurrent major depression is associated with hippocampal volume loss and that the degree of this change is determined by the duration of the illness. Considering the findings that depressed patients are frequently hypercortisolemic and that the degree of hippocampal atrophy in aged humans correlates with the degree of plasma cortisol increase over time and the current basal cortisol levels (Lupien et al. 1998), it has been proposed that the neuroendocrine changes in depression may account for the changes in hippocampal size seen in this disease. Importantly, these reductions in hippocampal volume which are also seen in patients with schizophrenia-a disease not particularly associated with enduring hypercortisolemia-do not necessarily reflect cell death (Nelson et al. 1998). Moreover, in post-traumatic stress disorder, decreased hippocampal volume is associated with normal or even reduced plasma and urine glucocorticoid contents (Bremner et al. 1999).

Studies in rats and tree shrews showed that psychological stressors may also induce atrophy in hippocampal CA3 pyramidal neurons which involves reversible remodeling of apical dendrites, a process where elevated excitatory amino acids are believed to be a primary cause, possibly amplified by increased glucocorticoids (Watanabe et al. 1992; Gould et al. 1997; Magariños et al. 1996, 1997). That factors-other than glucocorticoids-account for stress-induced reversible or permanent morphological changes in the hippocampus has also been underscored by a study in nonhuman primates (Leverenz et al. 1999). Based on works by Landfield et al. (1981), Kerr et al. (1991), and Sapolsky (1992), the study by Leverenz et al. (1999) administered high doses of glucocorticoids to aged macaques for 12 months, however, no evidence for decreased hippocampal volume, subfield volumes, subfield neuronal density, and subfield total neuronal number emerged. This finding is in accordance with a report by Müller and coworkers (1998), who studied postmortem brains of patients with depression and of patients treated with various synthetic corticosteroids and failed to observe morphological changes and signs of cell death under these clinical conditions. In this context, it is important to note that there is evidence that primates, unlike rats, have a relative paucity in GR, but a high density in mineralocorticoid (MR) in the hippocampus (Sánchez et al. 2000). Since, unlike cortisol, synthetic corticosteroids bind only poorly to MRs, studies using synthetic glucocorticoids, e.g., dexamethasone, in humans produce a situation where MRs remain unliganded in this brain formation. If it holds true that also in humans MRs are predominating over GR in hippocampus, dexamethasone pretreatment would deprive this brain region from CR signaling.

As reviewed by McEwen and coworkers (1992), adrenal steroids can exert a manifold of effects sometimes opposing on the rat hippocampus, i.e., they can be protective as well as deleterious. In line with this view, studies by Hassan et al. $(1996,1999)$ and Almeida et al. (2000) showed that corticosterone and dexamethasone given at low dosages can exert opposite effects on hippocampal cell viability. It is yet unclear whether these opposing effects are due to differences in penetration of these two corticosteroids through the blood brain barrier or whether they are due to differences in relative occupation of GR and MR. It also seems important to recognize in future studies that neurochemical and neuroanatomical effects of stress hormones can only be studied to a limited extent by exogenous administration of corticosteroids. Producing stress-like plasma cortisol concentrations results in a variety of central changes including altered expression of CRH and neurotrophins, which in turn may exert neuroprotective and other behavioral effects (Behl et al. 1997).

Another issue that deserves attention in future clinical and preclinical studies relates to the difference in the effects mediated by GR and MR (reviews: Trapp and Holsboer 1996a; de Kloet et al. 1998). To dissect their respective effects on cognition, studies similar to that of Newcomer et al. (1999), but using selective MR and GR agonists and antagonists, are needed. This is of particular importance if the provocative study of Sánchez and coworkers (2000) that reported a relative absence of GR in the primate hippocampus is corroborated. Based on measurements of GR and MR mRNA, Seckl et al. (1991) showed that in human hippocampus both receptors are highly expressed, but also confirmed that differences between species exist regarding the subfield distribution of GR and MR.

In the past, much emphasis had been put on the possibility that neurochemical and neuroendocrine changes associated with depression account for the morphological changes observed in the CNS of these patients. A recent study by Rajkowska et al. (1999) found reductions in density and size of neurons and glial cells in the dorsolateral prefrontal cortex of depressed patients and raised the question whether the observed specific histopathological changes in major depression may be due to a genetic predisposition for cortical cell changes. Studies that help to resolve this question are awaited and they need to include studies on gene networks that are involved in early brain development.

\section{Genetic Studies}

The patient population which would be ideally suited to study shifted HPA setpoints are subjects with inherited glucocorticoid resistance. These patients may either have a polymorphism in the GR gene or other alterations in genes, whose products are involved in glucocorticoid signaling. As a consequence of the ubiquitous GR resistance, elevated ACTH and cortisol secretion oc- 
curs without leading to symptoms of Cushing's syndrome. Nonetheless, other disturbances emerge that are mediated by those elevated adrenocortical hormones that bind to other steroid receptors, such as MR or androgen receptors. Thus, subjects with detected familial GR resistance were diagnosed to have hypertension, and among females hirsutism, menstrual irregularities, and acne were prevalent (Lamberts et al. 1992, 1996). Because such symptoms are not apparent in depression and because of the episodic course of this disease, it seems unlikely at first sight that the pathology underlying depression involves a major GR gene mutation.

Recent data, however, suggest that relative glucocorticoid resistance caused by GR mutations may not be as infrequent as previously thought (Koper et al. 1997). Thus, it seems pertinent to study whether psychiatric syndromes are more prevalent in patients with GR resistance and also whether such mutations may occur among psychiatric patients with dysregulation of the HPA system. It is of note that the presence of polymorphisms or mutations in the GR cannot be automatically inferred from glucocorticoid resistance because structure or assembly of cellular components, such as chaperones or other transcription factors involved in hor- mone signaling, may also be defective. On the other hand, the episodic nature of depression does not reject the possibility of GR gene polymorphism since compensatory mechanisms, which help to maintain stress hormone homeostasis most of the time, may be present. One such mechanism may include interaction of polymorphic GR with chaperones, which are responsible for individual GR-binding properties and in cooperation with other transcription factors can determine the activation or repression of gene expression through ligandactivated GRs (see Section III). The capacity of the chaperone/transcription factor assembly to compensate for functional deficits due to allelic GR variants may fluctuate and become less effective whenever other counteracting non-genetic factors (e.g., intracellular signals induced by environmental stressors) are activated.

Munich Vulnerability Study. In this light, the data from the Munich Vulnerability Study are of interest as they show that subjects who never suffered from a psychiatric disorder, but belong to families with a high genetic load for depression may display abnormal responses to the dex/CRH test (see Figure 1). These abnormalities were found to be constant over time and

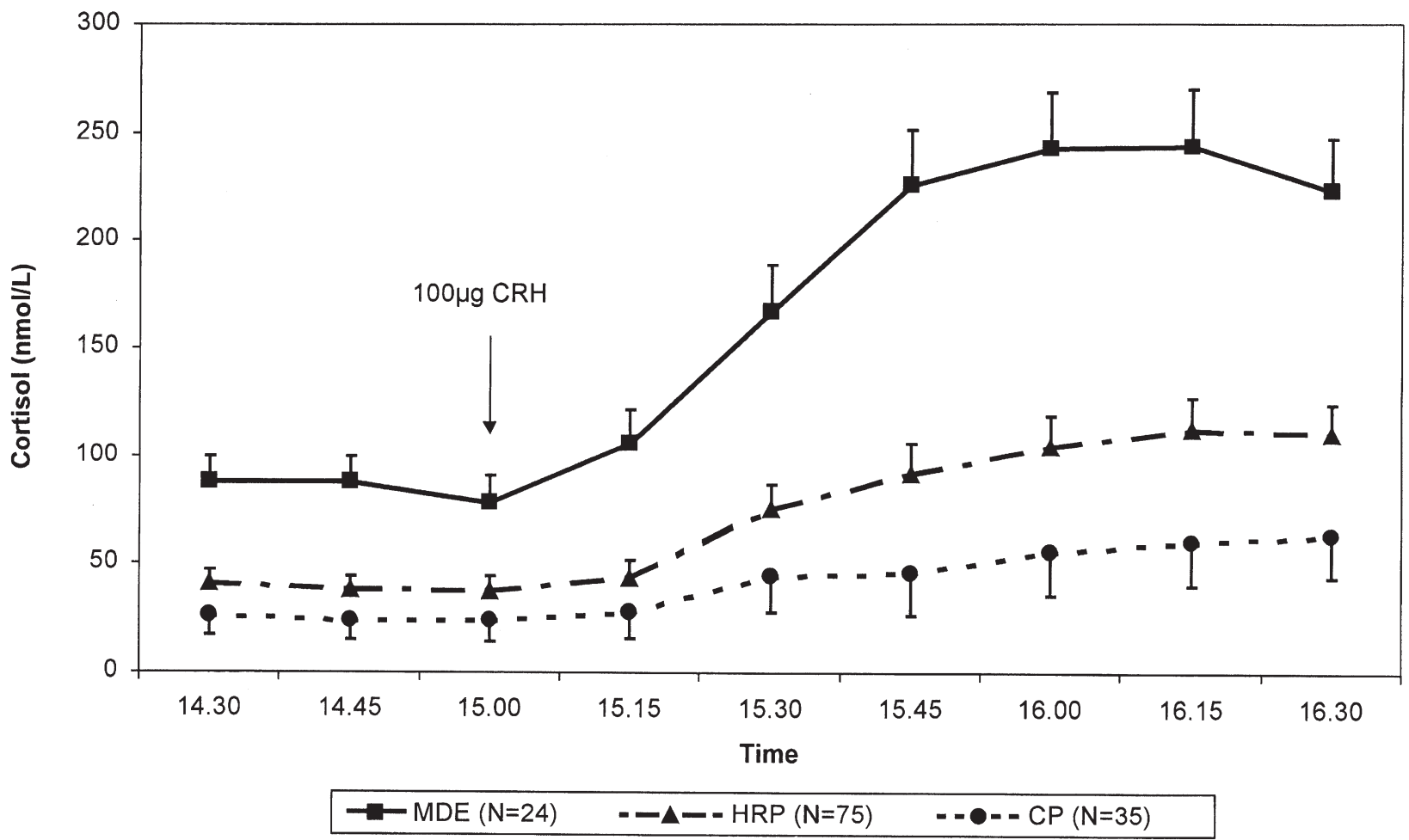

Figure 1. Munich Vulnerability Study. Seventy-five healthy probands selected from families with a high genetic load for depression (high risk probands, HRP) received $100 \mu \mathrm{g}$ human CRH (i.v.) at 15:00 h after pretreatment with an oral dose of $1.5 \mathrm{mg}$ dexamethasone at 23:00 $\mathrm{h}$ the day before. The plasma cortisol response (adjusted means \pm SEM; adjusted by age and sex) of the HRPs, matched patients with major depressive episode (MDE) and matched healthy controls (CP) from families without history for psychiatric morbidity were found to be significantly $\left(\mathrm{F}_{2,129}=16.36, p<.001\right)$ different. (Adapted from Holsboer et al. 1995 and additional data). 
those subjects showing these depression-like HPA changes were considered to be at risk for developing depression (Holsboer et al. 1995; Modell et al. 1998). The possibility that these HPA disturbances are acquired and rather reflect the stressful experience of having a family member suffering from a mood disorder than a genetic risk can be rejected, as only a fraction of about $20 \%$ of the probands show these alterations. Interestingly, this figure corresponds well with the calculated risk for developing depression in later life of high risk probands (Lauer et al. 1998). Whether it proves true that these individuals are indeed prone to develop depression is currently under investigation in longitudinal follow-up studies.

While it may well be that some of the individuals showing impaired corticosteroid receptor function and increased risk for depression do have a GR mutation, e.g., a single amino acid substitution in the ligand binding domain leading to reduced corticosteroid sensitivity, most genetic studies reported so far reject the GR gene as a possible locus of inherited pathology (DeteraWadleigh et al. 1992; Morissette et al. 1999). It would not be surprising, however, if genetic studies of large kindreds would reveal that GR-regulated genes or genes whose products are involved in stress hormone signaling are contributing to genetic susceptibility for depression.

\section{Preclinical Studies}

The CR hypothesis implies that intracellular signaling of adrenocortical steroids is impaired in specific areas of the brain, resulting in a number of changes in gene activity and neurotransmitter production involved in causality of depression. Particular emphasis is put on the interaction of hormone-activated GR and the effects on $\mathrm{CRH}$, which is believed to be a key neuropeptide in the pathogenesis of depression and other stress-related disorders (reviews: Owens and Nemeroff 1991; Holsboer et al. 1992).

There is no uniform relationship, however, between activated GRs and CRH secretion, as CRH is differentially regulated by GR in different regions of the brain. In most parts of the hypothalamic paraventricular nuclei (PVN), glucocorticoids suppress CRH and vasopressin as they suppress proopiomelanocortin, the precursor of ACTH of the anterior pituitary (Erkut et al. 1998). In some brain areas that include the central amygdala expression (Schulkin et al. 1998) and those nuclei of the PVN that project to the spinal cord accounting for CRH content in the cerebrospinal fluid (Swanson and Simmons 1989), corticosteroids upregulate CRH gene expression. Positive feedback of glucocorticoids on CRH synthesis and secretion in many brain areas is life-sustaining as it keeps the organism responsive to acute stressors under conditions of chronic stress. Elevated CRH in the amygdala, for example, is pertinent to maintaining appropriate emotional responsivity, particularly if stress exposure endures (review: Gray and Bingaman 1996).

The effects of CRH are mediated through specific receptors of which two different subtypes (CRH-R1 and CRH-R2) have yet been identified (Chalmers et al. 1995). Their neuroanatomical distributions suggest that they mediate different effects. Recent studies using antisense probes directed against CRH-R1 and CRH-R2 mRNA supported this notion as they showed that only reduced CRH-R1 levels produce anxiolytic effects in stressed rats (Liebsch et al. 1999). Reports on mouse mutants where one of these receptors was genetically inactivated confirmed that CRH-R1 mediates anxietylike behavior (Timpl et al. 1998; Smith et al. 1998). In contrast, two out of three studies where the CRH-R2 was invalidated noted increased anxiety-like behavior (Bale et al. 2000; Kishimoto et al. 2000; Coste et al. 2000) (see also Section II)

GRs are present in all rodent brain areas and are most abundant in the hypothalamus where they repress $\mathrm{CRH}$ and vasopressin gene activity. Most MRs in the brain are located in the hippocampus where they may be co-expressed with GR by many, but not all neurons. Hippocampal MRs are not selective for the prototypic mineralocorticoid aldosterone, but bind the glucocorticoid corticosterone (or cortisol in primates) with approximately tenfold higher affinity than GRs. This "nonselectivity" of brain MRs is determined by the fact that unlike in peripheral cells, the enzyme 11ß-hydroxysteroid dehydrogenase (11ßHSD) does not effectively exclude corticosterone or cortisol from MR-targets in the hippocampus. For example, in epithelial cells of the human kidney containing MR, this enzyme converts cortisol into cortisone, which binds only poorly to MR, allowing electrolyte homeostasis through aldosterone alone. In the hippocampus, a different $11 \beta \mathrm{HSD}$ isoform is present, which does not provide such selectivity (van Haarst et al. 1996a; Seckl 1997).

Because of the about tenfold higher affinity of "nonselective" hippocampal MRs for corticosterone, these receptors are already almost completely occupied at basal levels of corticosteroid secretion. On the other hand, hippocampal GRs are only occupied when corticosteroid levels increase under stress conditions or at the peak of the circadian rhythm of corticosteroid secretion. The coexistence of MRs activated at low corticosteroid concentrations, and of GRs activated only at high concentrations, allows the brain to differentially respond to the wide range of concentrations over which corticosteroids are secreted. These responses are extremely diverse and include steroid effects on cell membranes. At low concentrations, corticosterone maintains neuronal excitability which is a predominantly MRgoverned effect, whereas at higher hormone concentra- 
tions this is opposed by increasing GR activation (Joëls and de Kloet 1992). Specifically, under basal conditions where most of the MRs, but only a fraction of GRs are occupied, $\mathrm{Ca}^{++}$inward currents are small in hippocampal neurons; this results in a stable firing rate, thus contributing to the "proactive" role of corticosterone in maintaining homeostasis (review: de Kloet et al. 1998). Under stress, more GRs are activated and there is an associated increase in $\mathrm{Ca}^{++}$influx and responsivity to serotonin (5-HT), for example, increases. This condition is referred to as the "reactive" mode by which corticosteroids protect neurons through GR and MR by reinstating homeostasis (de Kloet et al. 1998). Thus, it is the ratio of activated MR and GR, which determines not only the effects of corticosteroids on hippocampal neurons themselves but also in their projection areas, e.g., the amygdala.

The effects of the predominant amino acid transmitters in the brain, glutamate and $\gamma$-aminobutyric acid (GABA), which mediate excitatory and inhibitory effects on synaptic transmission respectively, are also controlled by the relative occupancy and activation of MR and GR. This is demonstrated by the modulatory effects of these two receptors on long-term potentiation (LTP), a phenomenon that refers to strengthening of synaptic contacts by repeated stimulation. When glutamatergic afferents to the hippocampus, particularly the CA1 area, are repeatedly stimulated, prolonged enhancement of synaptic responsivity is observed as a consequence. It has been suggested that changes in LTP correlate with the capacity to learn and retrieve memorized material. The induction of LTP has been found to be critically determined by the level of corticosteroids. As recently argued by de Kloet and coworkers $(1998,1999)$, this effect can be best explained by appreciating the specific roles of MRs and GRs and the ratio of ligand activated MR/GR on neuronal activity in the hippocampus. Under resting conditions, when corticosteroid levels are in the normal range, LTP is most pronounced and the MR/GR ratio is high because MRs but not GRs are fully occupied. This condition is associated with a facilitated adaptation to stressful situations where MR activation accounts for behavioral reactivity to acute stressors. Under chronic stress, a reduced MR/GR ratio results from increased GR occupation under increased corticosteroid levels and a gradual desensitization of MRs which precedes GR desensitization; the latter changes are associated with reduced LTP. It seems likely that such changes in synaptic efficiency represent the neural correlate of memory impairment associated with hypercortisolism. These cognitive deficits not only include disruption of memory consolidation but also impaired memory retrieval (de Quervain et al. 1998). In this context, it is important to note that such effects do not solely result from altered corticosteroid effects in the hippocampus. For example, GR-mediated memory consolidation is also influenced by $\beta$-adrenoceptor stimulation in the amygdala (Roozendaal et al. 1999).

The interaction between hippocampal GR and MR also plays a role in HPA regulation of rat. Studies using MR antagonists or MR antisense probes under trough (morning) or stress conditions resulted in exaggerated HPA activity (Oitzl et al. 1994; Reul et al. 1997). Interestingly, the GR antagonist mifepristone (RU 486, also blocking progesterone receptors) when injected intracerebroventricularly (icv) has no effect on basal trough levels because of low GR occupancy during early daytime hours. Administration of the same drug in the early evening, when corticosteroid levels are rising, leads to further HPA activity increase. However, if RU 486 is injected directly into the hippocampus, this results in a decrease of ACTH and corticosterone secretion (van Haarst et al. 1996b), indicating that hippocampal GRs, when activated by corticosterone binding, are opposing the inhibitory effects of MRs. In other words, MRs mediate an inhibitory tone on the HPA system which is opposed by activated hippocampal GR. Following icv administration, the excitatory effect of GR antagonism at the hypothalamus overrides the inhibitory effect of GR antagonism at the hippocampus. If the balance between MR and GR is intact, then hypothalamic and pituitary GR capacity is sufficient to maintain adequate feedback upon CRH neurons and corticotrophic cells. However, if corticosteroid signaling is defunct, stress-elicited HPA activity is gradually shifted towards operating at higher setpoints, resulting in continuous HPA hyperdrive with accompanying behavioral effects due to CRH and vasopressin disinhibition as well as the many other sequelae of MR/GRdysbalance.

\section{The Nature-Nurture Conundrum}

The risk of developing depression or other major affective disorders is determined by a complex interplay between genetic susceptibility, environmental exposures, and aging. These influences also account for long-term changes in the regulation of the stress hormone system. This is particularly well illustrated by animal studies in which stressors were administered pre- or postnatally, followed by evaluations of HPA function and emotionality during later life. From these experiments, it was concluded that context and timing are critical determinants for predicting whether early stress exposure results in hypo- or hyperactive HPA-status. For example, Reul and coworkers (1994) stressed pregnant female rats with immunostimulants and observed that their pups had increased activity throughout adulthood.

Since the original report by Levine and Mullins (1966), it has been repeatedly demonstrated that the effect of postnatal "handling", i.e., a very brief daily separation of mother and pup results in reduction of both, emotionality and corticosterone secretion. Similarly, 
rats that had received normal maternal care (licking, grooming) during the first 10 days of their life had reduced plasma ACTH and corticosterone response to stress increased hippocampal GR and MR mRNA levels and decreased CRH mRNA when examined as adults. However, opposite effects were found, when these rats were severely traumatized postnatally by long motherpup separations alone or in combination with mild foot shocks (Ladd et al. 1996). These rats showed increased $\mathrm{CRH}$ concentrations in the median eminence, decreased number of CRH receptors and pituitary ACTH-secreting cells, and hypercorticoidism, thus bearing resemblance to the neuroendocrine state found in depressives. Of special importance is the observation that rats that were postnatally traumatized perform poorly in learning and memory tests, as opposed to rats that had received optimal maternal care (Plotsky and Meaney 1993). These findings, which were also confirmed in experiments with non-human primates (Coplan et al. 1996), suggest that early trauma may persistently weaken corticosteroid signaling, leading to disinhibited release of hypothalamic $\mathrm{CRH}, \mathrm{ACTH}$, and corticosterone which, in turn, may have behavioral sequelae that are related to a number of depressive symptoms. These data might even be extrapolated to the human situation, explaining why individuals who were abused during childhood may be more likely to develop depression in later life (Heim et al. 2000).

A number of different experiments, however, demonstrates that early trauma does not necessarily result in HPA disinhibition and cognitive impairment. Oitzl et al. (unpublished results, cited in de Kloet et al., 1998) used a different strain of rats than the previous investigators and showed that in Brown Norway rats, which are known for their long and healthy life spans, early trauma (i.e., long mother-pup separation) resulted in a bimodal distribution of cognitive performance in later life. Among animals that were traumatized as pups, these investigators identified good as well as poor learners but only a few intermediate learners. In the control group, however, the majority of rats were intermediate learners and only few good or poor learners were observed. The maternally-deprived rats had decreased GR expression in the hypothalamus and in the hippocampus. Among these traumatized rats, the good performers had lower plasma ACTH and corticosterone concentrations as compared to the poor performers. These experiments point to strain-dependent effects and suggest that it is the individual genotype that determines the consequences of early trauma on the HPAsystem and related behaviors. In view of this, the studies by Kendler and coworkers (1999) are important and have introduced an additional level of complexity as they show that the genetic endowment interacts with the environment; individuals with a high genetic risk for depression are more susceptible to the depressive episode-triggering effect of an adverse life event. In addition, genetic factors influence not only the sensitivity to potentially depressogenic life events, but also influence the likelihood to expose oneself to such an event. Hypothetically then, individuals with an inherited genetic trait that weakens stress hormone regulation through impaired corticosteroid receptor function may be more vulnerable to stressors and in addition they may select themselves into adversive situations which then trigger the onset of a depressive episode.

\section{MOUSE GENETICS AS A TOOL TO PROBE THE CR HYPOTHESIS}

\section{Knock-out or Transgenic Manipulation of CRH and Corticosteroid Signaling}

Mouse mutants with manipulations of the genes encoding either $\mathrm{CRH}$ or its receptors or CRs have been generated. As predicted from studies where CRH was injected into rodent brains, overexpression of $\mathrm{CRH}$ in mice results in an enhancement of anxiety-like behavior (StenzelPoore et al. 1994). Mice with deletions of the CRH gene exhibit normal stress-induced behavior, confirming that $\mathrm{CRH}$ may not be the only physiologically active ligand of $\mathrm{CRH}$ receptors. If $\mathrm{CRH}$ is absent, other neuropeptides such as urocortin or other yet-to-be identified molecules acting at CRH1 or CRH2 receptors (and possibly CRH receptors yet-to-be discovered) can serve as anxiogenic or depressogenic signals (Weninger et al. 1999).

Studies by Liebsch et al. $(1995,1999)$, Heinrichs et al. (1997), and Skutella et al. (1998), who used antisense probes directed against the mRNA-encoding CRH-R1 and CRH-R2 in rats, and also studies involving mouse mutants lacking CRH-R1, suggested that CRH-R1 mediates anxiety-like behavior (Timpl et al. 1998; Smith et al. 1998) (Figure 2). In contrast, CRH-R2 deficiency was shown to increase anxiety-like behavior in some (Bale et al. 2000; Kishimoto et al. 2000) but not all (Coste et al. 2000) studies, raising the possibility that the two so far identified CRH receptors mediate opposite effects on anxiety-like behavior. Recently, Radulovic and coworkers (1999) confirmed that the role of CRH in enhancing learning and precipitating anxiety-like behavior is brain area- and receptor type-dependent and that previous stressful experience can also modulate the CRH-mediated behaviors. CRH signaling through CRH receptors is further complicated because CRH is bound to CRHbinding protein (CRH-BP) which has an affinity for $\mathrm{CRH}$ that is equal to or greater than the respective $\mathrm{CRH}$ receptors (Potter et al. 1991). This 37-kDA protein binds $40-90 \%$ of total CRH and is present in most human brain regions at tenfold higher concentrations than total $\mathrm{CRH}$, which points to a major role of CRH-BP as regulator of CRH, "buffering" its actions under conditions of excessive release (Behan et al. 1995). 


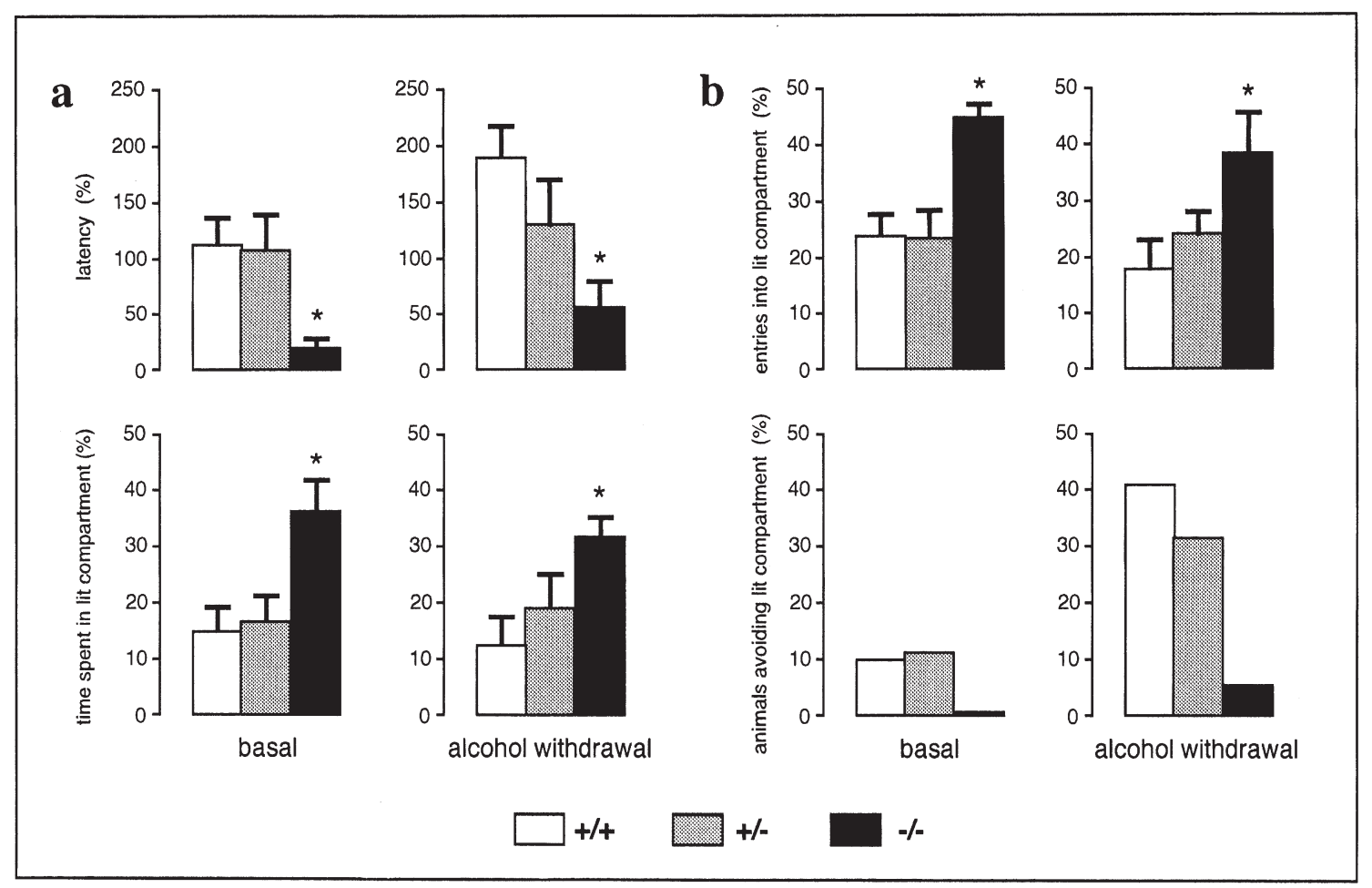

Figure 2. $\mathrm{CRH}_{1}$ Receptor Knockout Mouse. A mouse mutant lacking a functional $\mathrm{CRH}_{1}$ receptor by using homologous recombination in embryonic stem cells was generated where the coding sequences of the transmembrane regions V, VI, and VII, including the G-coupling protein domain and the intracellular cytoplasmatic trial were deleted. Analysis of their behavioral phenotype employing the light-dark box revealed that these mice showed less anxiety-like behavior at basal and stress (alcohol withdrawal) conditions. (a) Latency to enter the lit compartment was increased during withdrawal from comparison of 20 wild-type, 18 heterozygous, and 19 null mutants under basal and 22 wild-type, 22 heterozygous, and 20 null mutants under stress conditions, significant $\left(\mathrm{F}_{1,115}=8.4, p<.005\right)$ treatment effects emerged. (b) A similar effect of withdrawal stress was observed for animals avoiding the lit compartment. For latency, percent of time spent in the lit compartment and percent of entries into the lit compartment (genotype at $\mathrm{F}_{2,115}>12.1, p<.0001$ ). All these and data from Smith et al. (1998) are consistent with reduced anxiety-like behavior in the full or partial absence of $\mathrm{CRH}_{1}$ receptors. (From Timpl et al. 1998).

Compounds that displace CRH from this carrier in the brain produce anxiety-like and anorectic behavior, which is similar to the behavioral phenotype of mice where the gene for CRH-BP had been deleted (Karolyi et al. 1999). The loss of appetite seen in these animals is plausibly explained by the increased "free" CRH and urocortin levels since both of these peptides exert anorectic effects through CRH-R1 and/or CRH-R2. The behavioral role of urocortin still needs to be clarified. This neuropeptide binds with higher affinity to both CRH receptors and this may explain why anxiety-like responses to stressors in CRH null mutant mice are indistinguishable from wildtype mice (Weninger et al. 1999). In the absence of CRH, urocortin may bind to CRH-R1 compensating the loss of $\mathrm{CRH}$. Consistent with the notion that $\mathrm{CRH}$ and $\mathrm{CRH}$ receptors are involved in depression, anxiety and other stress-related conditions, transgenic mice which overexpress CRH-BP show decreased anxiety-like behavior and enhanced locomotor activity (Burrows et al. 1998).

The above mentioned studies confirmed the central role of $\mathrm{CRH}$ and its receptors in mediating stress-related hormonal and behavioral responses and are complemented by recent studies in mice with targeted mutations of corticosteroid receptors. In order to gain further insight into the causality of HPA aberrancies, the GR gene was disrupted, which resulted in a phenotype with 90-95\% lethality (Cole 1996). Survivors had excessive ACTH and corticosterone levels and almost absent adrenal medullas. In these mutants, Meijer and coworkers (1997) showed that the GR deficit results in impaired processing of spatial information. Because this behavior had previously been attributed to MR, these authors suggested that MR effects in the hippocampus require intact GR function which is consistent with a role for GR/MR heterodimers in mediating these effects (Trapp et al. 1994). The fact that only a minor fraction of litters survives the disruption of GR suggests that these animals were the few that could successfully compensate GR deficiency, which has profound peripheral effects.

The true nature of these complex compensatory mechanisms is not clear and it will be difficult to identify 
their specific involvement in the observed behavioral phenotype. Therefore, the recently developed mouse mutants where the GR knockout was restricted to neural tissue using the Cre/LoxP-recombination system should be more promising for studies of the effects of GR disruption in the brain (Tronche et al. 1999). In these mice, exon 3, encoding the first zinc-finger GR DNA binding domain, was flanked by LoxP sites. Crossing these mice with mice that express the nestin-Cre transgene resulted in animals where GR protein was absent only in neurons and glia cells. In these mice, CRH was elevated in the hypothalamus and ACTH and corticosterone were hypersecreted indicating that ligand-activated pituitary GRs (which remained intact) are unable to fully compensate for effects of hypersecreted CRH through suppression of POMC gene expression. These mice also showed signs of reduced anxiety and impaired stress response suggesting that loss of corticosteroid signaling through GR in the brain has direct consequences for emotional behavior (Tronche et al. 1999).

These initial studies did not address whether GR deletion leads to reduced CRH gene expression in the central amygdala. In this brain region, $\mathrm{CRH}$ is believed to be enhanced by activated GR and the absence of neuronal GR function could plausibly result in decreased anxiety-like behavior (Schulkin et al. 1998). Notably, even cell-specific gene disruption does not resolve the issue of compensatory mechanisms which are perhaps also reflected in the surprising dissociation of ACTH and corticosterone secretion in these mice. Given the specific role of hippocampal MR in behavior and neuroendocrine regulation, it would be of great interest to study a mouse mutant where the MR gene deletion is restricted to the hippocampus. The MR knockout mice obtained by gene targeting that is not tissue specific, died between postnatal day 8 and day 13 due to massive sodium loss and subsequent electrolyte disturbance (Berger et al. 1998). Studies using techniques to inactivate MR selectively in the hippocampal formation are now warranted to better understand the role of this receptor, which in non-human primates is believed to be the predominant corticosteroid receptor in this brain region (Sánchez et al. 2000).

\section{Transgenic Mice Expressing GR Antisense}

Pepin and coworkers (1992) generated a transgenic mouse in which an 1815 base pair fragment of the 3' non-coding region of the GRCDNA, downstream from a $2.3 \mathrm{~kb}$ Eco R1/Hind III human neurofilament promoter element, was inserted into the mouse genome. This resulted in a mouse expressing GR antisense mainly in neuronal tissue and this mutant was expected to be a well-suited animal model of depression associated with impaired GR function (Pepin et al. 1992). This transgenic mouse was extensively studied and the main findings that emerged were the following: 1) these mice needed higher dexamethasone dosages than control mice in order to display corticosterone suppression under basal conditions or following CRH (Stec et al. 1994); 2) $\mathrm{CRH}$-elicited $\mathrm{ACTH}$ was higher in transgenic mice but corticosterone was lower in comparison to controls (Barden et al. 1997); 3) these mice showed decreased corticosterone response to exogenous ACTH (Barden et al. 1997); 4) when stressed, these mice showed increased ACTH levels, whereas corticosterone levels remain unchanged (Karanth et al. 1997); 5) Dijkstra et al. (1998) showed reduced activity of CRH neurons in the PVN of these mice and decreased sensitivity of pituitary CRH-R1 mRNA to stimulus-induced desensitisation; 6) these mice displayed an enhanced locomotorstimulating effect to morphine, a response that is reflected by an enhanced dopaminergic activity within the mesolimbic system (Spanagel et al. 1996); 7) in these mice, responses to endotoxin were aberrant as noted by Linthorst and coworkers (1999), confirming that immune function is critically determined by appropriate GR function; 8) several studies (e.g., Montkowski et al. 1995; Rousse et al. 1997; Rochford et al. 1997; Ströhle et al. 1998) showed that these mice have impairments in learning and memory paradigms which are also influenced by age; 9) Steckler et al. (1999) concluded that allocentric spatial navigation is impaired whereas egocentric navigation is unimpaired. The latter authors suggested that the observed effects were due to hippocampal dysfunction secondary to GR deficiency and possible compensatory changes. From their study follows that the observed deficit is related to a general impairment in storage or retrieval of information; 10) Steckler and coworkers (2000a) further concluded that the behavioral phenotype of GR-impaired transgenic mice is characterized by altered motivation and enhanced impulsive responding rather than from mnemonic deficiency; 11) Linthorst et al. (2000) studied putative disturbances at the synaptic level in these mice employing an in vivo microdialysis probe. In transgenic mice, serotonin release was higher than in control mice when exposed to rats, usually perceived as a profound stressor by mice. Paradoxically, transgenic mice did not show typical stress-like behaviors (e.g., freezing), but exhibited arousal behavior (e.g., exploration and approach toward a rat). The exaggerated serotonin release in these mice perhaps reflects the reciprocal interaction between CRH and raphe-hippocampal serotonin activity. Chronically elevated levels of central CRH have been shown to cause hyporesponsiveness of hippocampal serotonin following an acute stressful stimulus (Linthorst et al. 1997). In these transgenic mice, hypothalamic release of CRH is low, possibly explaining the enhanced serotonin release (Dijkstra et al. 1998).

Critical appreciation of the herein referred to studies using mouse mutants allows one to conclude that ma- 
nipulations of the expression of $\mathrm{CRH}$ and its receptors have largely confirmed what was expected from pharmacological experiments. Alteration of GR gene expression (knockout or antisense expression) has led to several unexpected findings, e.g., reduced anxiety-like behavior in mice with GR gene disruption in the CNS and decreased CRH expression in hypothalami of mice expressing GR antisense. It is of note that none of the mouse mutants generated so far, can be viewed as animal model of a specific psychiatric disease defined by common diagnostic procedures. However, as discussed below these mouse mutants seem to be of great value to study several selected symptoms such as anxiety, abnormal stress response, cognition, withdrawal from drugs of abuse, appetite, reproductive behavior, sleep, etc., that are associated with HPA disturbances.

\section{MOLECULAR MECHANISMS OF CORTICOSTEROID SIGNALING}

\section{Cytosolic Activities}

The translation of the corticosteroid signal into a cellular response can be dissected into three steps: 1) entry of corticosteroids into the cell which occurs by passive transmembrane passage; 2) binding to corticosteroid receptors whose binding capacity is determined by chaperone-assisted folding; 3 ) trafficking to the nucleus that involves dissociation of chaperones and cooperative actions of transporters; and 4) nuclear actions of ligandactivated receptors either through DNA binding at specific response elements (GRE) or through protein-protein interaction with other transcription factors.

The first step in corticosteroid signaling, its passage through the cell membrane, is regarded as a passive process due to the lipophilic nature of steroid molecules. Because the affinity of steroid molecules for intracellular receptors is higher than for extracellular transport proteins (corticosteroid-binding globulin), there is enrichment of corticosteroid molecules within target cells. Only recently, specific interactions of corticosteroids with molecules residing within the cell membrane have been identified. From studies with ion channels composed of $\mathrm{GABA}_{\mathrm{A}}$ receptor subunits, evidence emerged that so-called neuroactive steroids (usually reduced at the ring A of the steroid molecule) interact by modulating chloride ion conductance (reviews: Paul and Purdy 1992; Rupprecht and Holsboer 1999).

In non-mammalian cells, Orchinik and coworkers (1991) found preliminary evidence for a corticosterone receptor-like structure in synaptic membranes and others (Alléra and Wildt 1992; Lackner et al. 1998) suggested the existence of a glucocorticoid carrier within the membrane of rat liver cells. It is yet unresolved whether such mechanisms also exist in neurons. These studies need to be substantiated in various tissues be- fore the possibility of membrane-mediated actions can be recognised as crucial step in steroid signaling. That the access of corticosteroids to nerve cells can also be limited by an active process has recently been shown by Schinkel et al. (1995). Uptake of moderate amounts of dexamethasone was found to be limited by a multidrug resistance gene product, a P-glycoprotein extrusion pump that actively exports synthetic corticosteroids, but not naturally occurring hormones out of the cell. Mice lacking this gene have a higher central uptake of some synthetic neuroactive compounds (Uhr et al. 2000) including dexamethasone (Meijer et al. 1998).

When entering the cell, the corticosteroid molecule binds to MR or GR which are part of a dynamic multiprotein complex, composed of the steroid receptor and an array of chaperones which include heat shock proteins. Chaperones function as assembly systems for steroid receptors as well as other protein molecules involved in corticosteroid signal transduction. The basic assembly system (termed "foldosome") has been reconstituted in vitro and was shown to require hsp90, hsp70, p60/hop (hsp70-organizing protein) and hsp40 (Pratt and Dittmar 1998). The foldosome initially associates with the nonsteroid binding state of the receptor. Under in vivo conditions the foldosome may require additional proteins, e.g., hip (hsp70-interacting protein). In the final heterocomplex, hop is replaced by immunophilins, e.g., FKBP 51 (also termed FKBP 59) or FKBP 52 (also termed FKBP 59, p59, or hsp56). This heterocomplex is further stabilized by $\mathrm{p} 23$, a protein that binds directly to hsp90 and maintains the corticosteroid receptor in a conformation that facilitates hormone binding. It is of note that the stepwise assembly and conformational maturation of the heterocomplex requires energy input through ATP. Both chaperones, hsp90 and hsp70, are ATP-binding and -hydrolyzing proteins. The role for hsp90 and the importance of ATP to maintain receptor conformation has been studied using the benzoquinone geldanamycin, which occupies the nucleotide binding site on hsp90 and prevents the switch to its ATP-bound conformation. Through this inhibition, the corticosteroid receptor is prevented from being assembled into the heterocomplex and is kept in a low affinity state for its ligands and steroid receptor-induced transactivation is therefore abolished.

Another example how chaperoning determines CR signaling is that the ratio between $h s p 70$ and a protein that binds hsp70 as a co-chaperone, termed BAG-1 (Bcl2-associated gene product-1) modulates the glucocorticoid-binding activity of the GR hsp90 heterocomplex, as increasing BAG-1 inhibits GR folding and thus decreases corticosteroid signaling (Kanelakis et al. 1999; Nollen et al. 2000). From these findings, it can be concluded that changes in the chaperone assembly can have a manifold of effects on activation and repression of GRE-regulated genes. The relevance of stoichiometric changes in chap- 
erone expression has been demonstrated in the squirrel monkey, a species with excessively high cortisol levels, but no signs of Cushing's syndrome (Chrousos et al. 1982). This discrepancy is currently best explained by a markedly decreased binding affinity of GR, due to an overexpression of immunophilin FKBP 51 in squirrel monkey (Reynolds et al. 1999).

Once the steroid is bound, it induces a conformational change in the receptor and subsequently heat shock proteins and immunophilins dissociate, allowing for nuclear actions of activated MRs and GRs. This dissociation equilibrium is a dynamic process and GR and MR can be recycled by reassociating with chaperones. There is increasing evidence that (co)chaperones are not only important for GR activity in the cytosol, but also in the nucleus. For example, hsp90 may participate in the nuclear-cytoplasmic shuttling of GR (Kang et al. 1999) and it may also facilitate chromatin recycling of GR (Liu and DeFranco 1999). More recently, the cochaperone RAP 46 (also known as HAP 46 or BAG-IL) which can associate with hsp90 and GR has been identified as a non-specific DNA-binding protein which may act as a general transcriptional activator (Zeiner et al. 1999), on the other hand, Schneikert and coworkers (1999) reported that RAP 46 downregulates GR-mediated transactivation, but not transrepression. Altogether, it becomes clear from these few selected examples that future research linking HPA function with causality of depression and course of treatment needs to include studies on the role of chaperones in GR signaling.

\section{Nuclear Activities}

Ligand-activated GRs and MRs can either activate or deactivate expression of target genes. Activation occurs through formation of GR-GR and MR-MR homodimers or GR-MR heterodimers, which bind to short palindromic DNA sequences called glucocorticoid response elements (GRE, see above) in the promoter region of corticosteroid-responsive target genes. Whether the response elements to which receptor homodimers or heterodimers can bind are all identical is not yet known. The role of activated GR and MR functioning as nuclear transcription factors is to recruit various factors that are able to remodel the chromatin structure at the promoter of the target gene and to recruit and maintain a transcriptional pre-initiation complex. A fine-tuned mechanism orchestrates gene activation through GRE and only a few aspects highlighting possible causes of impaired GR and MR function at this level and consequences for potential targets are briefly discussed (reviews: Beato et al. 1995; Mangelsdorf et al. 1995; Shibata et al. 1997; Freedman 1999) (see Figure 3).

When bound to DNA, the steroid receptor associates with coactivators, such as steroid receptor coactivator 1 (SRC-1, member of the p160 family). If SRC-1 is coex- pressed in an assay system analysing GRE-regulated gene expression (such as the mouse mammary tumor virus, MMTV) then the transcriptional efficacy of GRs is strongly enhanced. The situation is even more complex as the enhancement of GR by the coactivator SRC-1 is amplified by CBP, a protein that binds CREB (cyclo AMP response element binding protein). This synergy may function through more efficient recruitment of basic ("general") transcription factors (GTF) and stabilization of the preinitiation complex, thus enhancing mRNA synthesis by polymerase II. SRC-1 and CBP are only two of the many recently discovered coactivators of GR-mediated transcriptional activity and the mechanism by which they drive transcription is only poorly understood. One such mechanism is the acetylation of histones by SRC-1 which results in localized chromatin remodelling and assembly of the basal transcription machinery into a stable preinitiation complex (Spencer et al. 1997). While all coactivators identified so far are proteins, a recent study by Lanz and coworkers (1999) identified an RNA molecule that fulfills all characteristics of a coactivator of SRC-1. This RNA transcript called SRA (steroid receptor RNA activator), if coexpressed in assays of steroid receptor-mediated transactivation, can induce a tenfold enhancement of receptor gene activity, which can be abolished when SRA antisense oligodeoxynucleotides are added to the cells. It is not clear whether modulation of GR mediated transactivation by RNA molecules is a physiologically relevant mechanism. This theoretical possibility, however, opens up many new opportunities to interfere with glucocorticoid actions in the nucleus.

Reduction of gene expression by glucocorticoid receptors can be achieved through DNA-bound GRs as well as by interference of GRs with those nuclear transcription factors, that otherwise enhance gene activity. The physiological role of response elements, which reduce transcription when GR dimers are bound, is still debated. Only in a few cases, for example, the negative GRE-mediated regulation of the proopiomelanocortin gene expression, a mechanism requiring DNA-binding receptor dimers, seems to be effective (Drouin et al. 1993). Another example is that of the recently localized cis-acting site of the human $\mathrm{CRH}$ promoter that mediates negative regulation by ligand-activated GR (CRHnGRE) (Malkoski et al. 1997). Under the experimental conditions used (transient expression in mouse corticotroph-derived AtT-20 cells), the CRHnGRE, however, can be activated by cAMP or CREB (Malkoski and Dorin 1999).

To further appreciate these findings in the context of the CR hypothesis, it would be desirable to reproduce these findings under conditions that allow extrapolations on the in vivo condition. Still another possibility of GR-induced reduction of gene activity is that some molecules associated with GRE bound receptors act as corepressors (see Figure 3). Such a functional interaction be- 

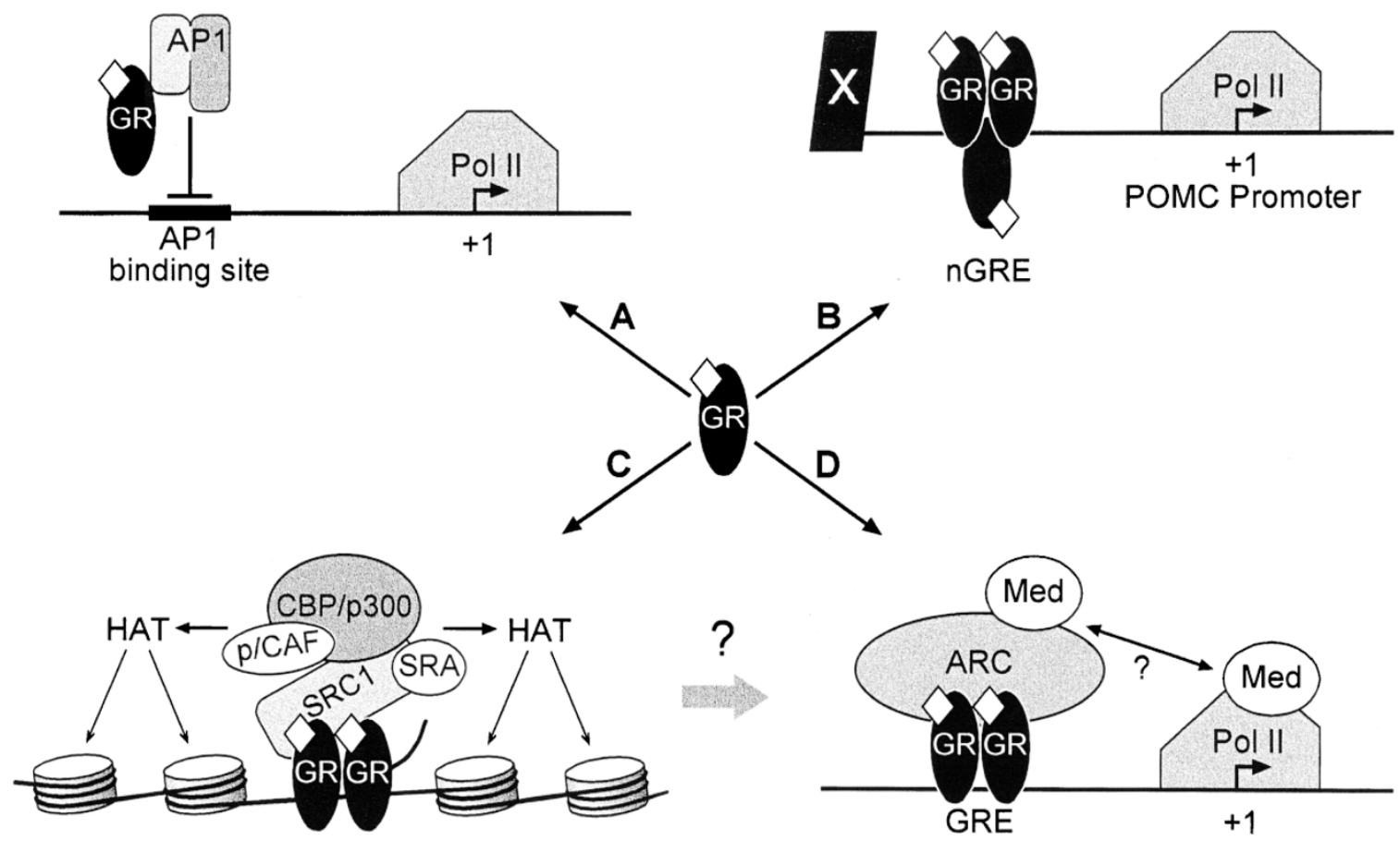

Figure 3. Positive and Negative Regulation of Gene Transcription by GR. (A) Transrepression. Ligand-activated GR interacts with transcription factors like AP1 or NF- $\beta$ by direct protein-protein contacts, thereby preventing them from binding to their cognate DNA sites and from activating the RNA polymerase II initiation complex. (B) $n G R E s$. Negative regulation of gene transcription by ligand-activated GR in the POMC promoter involves binding of a GR trimer to a negative GRE (nGRE), thereby presumably intervening with upstream activating factors $(X)$. Negative regulation at other nGREs, e.g., in the gene promoters of $\mathrm{CRH}, \mathrm{GnRH}$, prolactin, IL-1 3 , and osteocalcin involves the interplay with other transcription factors, e.g., AP-1, Pbx, and Oct-1. (C) Chromatin Remodeling. Coactivators of the p160 family such as SRC-1 (= NCoA-1), RAC3, GRIP1 (= TIF2 $=\mathrm{NCoA}-2), \mathrm{p} / \mathrm{CIP}$ (= ACTR), AIB1, and TRAM-1 bridge the DNA-bound GR dimer with a complex consisting of CBP or its homologue p300 and p/CAF. In addition, a ribonucleoprotein complex containing SRA (steroid receptor RNA activator) . RNA probably stabilizes the interaction of p160 proteins (e.g., SRC-1) with GR. Since the p160 family members, CBP/p300 and $\mathrm{p} / \mathrm{CAF}$ all possess HAT (histone acetyl transferase) activity, this complex would result in remodeling the chromatin structure, thereby opening promoter regions. Moreover, CBP has the capability to directly bind to components of the basal transcription machinery. (D) Transactivation. DNA-bound GR dimer recruits the activation complex DRIP (probably identical to ARC and TRAP) which leads to activation of the RNA polymerase II complex. Mammalian homologues of the mediator/ SRB proteins have been found both as components of the DRIP complex and associated with the CTD of RNA polymerase II, a functional interaction between these two protein complexes. Whether the chromatin remodeling complex $(\mathrm{C})$ and the transactivating complex (D) function subsequently or concomitantly is not clear yet. Abbreviations: ACTR, activator of the thyroid and retinoic acid receptors; AIB1, amplified in breast cancer 1; ARC, activator-recruited cofactor; CBP, CRE binding protein; $\mathrm{CRH}$, corticotropin-releasing hormone, DRIP, vitamin D receptor-interacting protein; GnRH, gonadotropin releasing hormone; GRE, glucocorticoid responsive element; GRIP1, glucocorticoid receptor interacting protein; HAT, histone acetyl transferase; Med, Mediator; NCoA, nuclear receptor coactivator; p/CAF, p300/CBP-associated factor; p/CIP, p300/CBP-cointegrator associated protein; POMC, pro-opiomelanocortin; RAC3, receptor-associated coactivator; SRA, steroid receptor RNA activator; SRC-1, steroid receptor coactivator 1; SRB, suppressor of RNA polymerase B mutations; TIF2, transcriptional intermediary factor; TRAM-1, Thyroid hormone receptor activator molecule 1; TRAP, thyroid receptor-associated protein.

tween a latent transcription factor called Stat5 (signal transducer and activator of transcription) and the GR has been shown (Stoecklin et al. 1996). The GR can form a physical complex with Stat5, which decreases its DNA binding and thus GR-driven transactivation. This effect, first demonstrated in the mouse mammary tumor virus (MMTV) promoter (which contains four copies of the GRE), required phosphorylation and dimerisation of Stat5. The MR is similarly affected by Stat5, however, at a lower rate (Stoecklin et al. 1997).
The best studied example of how corticosteroid receptors negatively regulate gene transcription through protein-protein binding is a group of negatively GRregulated genes that contain an AP-1 (activating protein 1) binding site in the promoter. AP-1 is a dimer composed of Jun and Fos (review: Pfahl 1993). If GR is ligand-activated it interacts as a monomer with the Jun/Fos dimer resulting in decreased AP-1 driven transcription (Figure 3). An example where both mechanisms (transactivation through genomic action and 
transrepression through protein-protein interaction) occur simultaneously is the effect of ligand-activated GR on the activity of NFKB (nuclear factor $\kappa \mathrm{B}$ ), a factor which is induced by many stimuli, predominantly those related to inflammation. In its inactive form $\mathrm{NF \kappa B}$ (composed of a p50-p65 heterodimer, although other members of the RelA family can also constitute this transcription factor) is complexed by the inhibitory Iк $B$ subunit. When activated by corticosteroids, GRs can activate IкB expression through a GRE in the IкB gene promoter (Auphan et al. 1995). Furthermore, activated GRs interact with p65 and may therefore prevent p50p65 binding to $\kappa \mathrm{B}$ sites in the promoters of cytokines or cell adhesion factors which mediate inflammatory response (Caldenhoven et al. 1995). This dual action of corticosteroids through GR-protein interaction and gene activation works concurrently to suppress clinical symptoms associated with inflammation (Wissink et al. 1998; van der Burg et al. 1997).

Another mechanism which may reduce the efficiency of GR induced gene activation is altered splicing of GR pre-mRNA, resulting in overexpression of the GR $\beta$ variant that is devoid of transactivity. Heterodimerisation of GR $\beta$ with the transactive GR $\alpha$ results in diminished GRE regulated gene activity (Bamberger et al. 1995). A nuclear orphan receptor has also been identified that represses GR mediated transcriptional activity (Trapp and Holsboer 1996b). Other orphan nuclear receptors that interfere with GR and are directly involved in HPA activity belong to the nurr1/ nur77 subfamily. These molecules do not require ligand binding and can confer transcriptional activity through specific response elements without ligand activation (Drouin et al. 1998; Murphy and Conneely 1997). Nur77, which transactivates either as a monomer or as a dimer through specific response elements, is of particular importance for the maintenance of basal ACTH secretion. Only during stress, when CRH is released from the hypothalamus reaching the anterior pituitary through portal vessels, CRH-R1 receptor-mediated enhancement of proopiomelaonocortin gene expression and subsequent increased secretion of ACTH from corticotrophs occurs.

While most experiments elucidating cellular effects of ligand-activated corticosteroid receptors have been conducted in artificial cell systems, some of the conclusions drawn so far have been corroborated in a mouse mutant where a specific point mutation was introduced into the GR (Reichardt et al. 1998). These authors mutated the GR gene by exchanging alanine and threonine, in position 458 . This was based on a study by Heck and coworkers (1994) who observed that this mutation, which is located in the second zinc-finger in the DNA binding domain of the GR, abolishes receptor dimerisation and thus DNA binding. In mice homozygous for this point mutation, CRH expression was unimpaired, whereas POMCmRNA and ACTH were elevated. This finding is consistent with a negative regulation of the $\mathrm{CRH}$ gene through GR monomers that do not bind to DNA but transrepress through protein-protein interaction. Alternatively, the activation of a negative GRE in the CRH promoter may not require GR dimerisation (Malkoski and Dorin 1999). In contrast, pituitary corticotrophs require GR dimerisation which is in accord with DNA binding at a negative response element or interaction as a dimer with nur77 (Philips et al. 1997).

The examples referred to in this section show that a great number of possibilities exist for changing the setpoint of an individuals HPA activity. It is important to note that such setpoints are variable across individuals, but fairly stable intra-individually (Huizenga et al. 1998). This is even true among individuals with an increased genetic risk for depression where alterations of this setpoint are believed to be causally related to pathogenesis (Modell et al. 1998).

\section{CONSEQUENCES FOR FUTURE DRUG TREATMENT OF DEPRESSION}

\section{Current Antidepressants}

Antidepressants are clinically effective not only in depression and panic disorder, but also in generalized anxiety and social phobia, and constitute one of the most successful treatment modalities in medicine. In contrast to this clinical situation, elucidation of the mechanisms of action of these drugs has been less successful. The hypothesis that has dominated the psychopharmacology of depression for decades is based on the assumption that a biogenic amine-deficiency underlies mood disorders and that this can be remedied by inhibition of presynaptic reuptake transporters of serotonin (synthesized and released from dosal raphe nucleus) and/or norepinephrine (originating from the locus coeruleus), thus increasing the transmitter concentration at postsynaptic sites. This hypothesis does not explain why it takes many weeks, often months, before antidepressants become effective, whereas reuptake inhibition occurs immediately.

A refinement of the monoamine hypothesis was forwarded by studies that depleted central serotonin and norepinephrine bioavailability. These studies found that normal individuals do not develop depressive symptoms when serotonin or norepinephrine is depleted through specific diets (Delgado et al. 1990). It was found, however, that patients having previously responded to a selective serotonin reuptake inhibitor (SSRI) worsen clinically when experimentally deprived from serotonin, but not from norepinephrine. In turn, those patients having responded to a norepinephrine reuptake inhibitor had increased depressive symptomatology when norepinephrine depletion was induced 
through diet with methyl para-tyrosine (Delgado et al. 1992). It was concluded from these studies that antidepressants rather than acting through a specific pharmacological mechanism may trigger a long cascade of events which then converge to act through a final common pathway. The view that the primary effect of antidepressant-induced changes on uptake transporters is remote from the therapeutically-relevant action is also fueled by a recent study that failed to find a difference in the clinical efficacy of the selective serotonin reuptake inhibitor paroxetine when compared to tianeptine, which enhances serotonin reuptake (Nickel et al., unpublished results), which is in accord with results of a study that compared tianeptine with fluoxetine (Lôo et al. 1999).

Two new hypotheses, which are complementary rather than mutually exclusive, have been forwarded to explain how antidepressants work at the neurobiological level. One hypothesis, developed by Duman et al. (1997), focusses on the effects of activation of the cAMP cascade through cell membrane receptors, followed by enhanced induction of CREB and hippocampal brain derived neurotrophic factor (BDNF). The other hypothesis, which is the fundament of this treatise, submits that antidepressants act through improving CR function. In the CNS, these modulations also affect brain regions not or only indirectly connected to the peripheral HPA system, which regularly stabilizes under the influence of antidepressants.

Studies supporting the cAMP/CREB/BDNF-hypothesis documented that the expression of CREB is enhanced by antidepressants and electroconvulsive treatments. In addition, the stress-induced decrease of BDNF is blocked by antidepressants. Because the BDNF gene contains a cAMP response element (CRE) to which phosphorylated CREB (P-CREB) binds and enhances transcription, it is assumed that activating CAMP through increased amine binding at $\mathrm{G}$ protein-coupled cell membrane receptors will ultimately result in increased expression of BDNF. This neurotrophic factor, when injected centrally in high dosages to rats produces changes in behavior that are reminiscent of changes induced by antidepressants (Siuciak et al. 1996). The antidepressantinduced expression of BDNF would also explain the beneficial effect of these drugs upon neuronal survival and growth of hippocampal neurons which are believed to be potentially endangered as a consequence of the neuroendocrine changes during a depressive episode (see Section I).

As the authors of this hypothesis point out themselves, CREB and BDNF regulation are not the sole targets of antidepressants (review: Duman et al. 1997). Their hypothesis rather exemplifies a new approach in exploring how antidepressants may exert their therapeutic of action beyond the receptor level. More specifically, studies related to the cAMP/CREB/BDNF- hypothesis will prove whether the absolute amount of CREB, increased by antidepressants is relevant for transactivation of CRE-regulated genes. In the future, the degree of phosphorylation of CREB (P-CREB) following acute and long-term treatments with antidepressants needs to be analysed, because only P-CREB can bind to DNA, thereby accounting for CRE-induced transactivation. Such studies are pertinent since Rossby and coworkers (1999) examined the long-term effects of venlafaxine, which inhibits both, the serotonin and the norepinephrine reuptake transporter. These authors reported that CREB expression was unchanged by venlafaxine, whereas the transcriptionally active phosphorylated P-CREB was reduced in the cortex of rats. Because neither endogenous nor cAMP-stimulated protein kinase A (PKA) activity was changed by venlafaxine, the decrease of P-CREB was not attributed to decreased cAMP. If this venlafaxine-induced decrease in CREB phosphorylation is also effective in the hippocampus, BDNF expression would be expected to be decreased by this drug in this brain area. This would be not consistent with a general enhancement of BDNF expression by effective antidepressants.

The important information obtained from these studies is that antidepressants exert nuclear effects that are not necessarily mediated by the well-characterized signaling pathways. This seems particularly true when one tries to unify the CR hypothesis and the cAMP/ CREB/BDNF hypothesis. First, there is substantial cross-talk between CR signaling and CREB phosphorylation. GR does not prevent CREB binding at DNA but physically associates with CREB and thus decreases phosphorylation of CREB. Provided that the observation of Rossby and coworkers (1999) is not limited to the specific effects of venlafaxine in the cortex, then decreased P-CREB should result in decreased expression of $\mathrm{CRH}$, which contains a CRE in its promoter (Seasholtz et al. 1988; Spengler et al. 1992). Legradi and coworkers (1997) observed that glucocorticoids can abolish CREB phosphorylation in CRH neurons. Thus, if GR signaling is impaired, CRH expression through P-CREB is enhanced and this effect is counteracted by venlafaxine (and perhaps also by other antidepressants) which reduces P-CREB (Rossby et al. 1999). Still, other impairments in cAMP-PKA pathways may possibly exist in depression (Shelton et al. 1999), including impaired CRE-regulated gene expression which can be restored by antidepressants. Since cross-talk between cAMPPKA pathways and corticosteroid signaling is well documented, impaired corticosteroid receptor function could not only result from altered cAMP-PKA activity but may in turn account for disturbances in cAMPPKA-elicited activation of CRE.

The second observation that allows both hypothesis to converge is that postreceptor effects of antidepressants do not necessarily implicate cell membrane receptor $G$ pro- 
tein cAMP-PKA pathways or ion channel-mediated activation of kinases. Inasmuch as BDNF can be regulated by other mechanisms than CAMP-CREB, corticosteroids can also be functionally regulated by antidepressants in the absence of adrenoceptors. Pepin and coworkers (1992) have demonstrated increased GR promoter activity in fibroblast cells that are devoid of aminergic receptors, and other studies (Rossby et al. 1995; Eiring and Sulser 1997) found that increased hippocampal GR mRNA expression is independent of increased adrenoceptor stimulation and, in general, independent of norepinephrine bioavailability. In this context, another interesting aspect that has been introduced by Pariante et al. (1997), is that GR trafficking can be induced by antidepressants independently of ligand binding and receptor activation, thus pointing to an interaction of antidepressants with chaperones, and an interference with the energy supply (ATP) necessary to maintain corticosteroid receptors in a hormone-binding mode through energyrequiring activities of chaperones.

In vivo experiments showed that rats, when treated for five weeks with different antidepressants (MAO inhibitors, SSRIs, norepinephrine reuptake inhibitors, serotonin reuptake enhancer), displayed decreased baseline and stress-induced levels of plasma ACTH and corticosterone. Upon analyzing the capacity of MR and GR in the hippocampus of these rats, it was found that the first change was seen in MR binding, which increased after one week of treatment (Reul et al. 1993, 1994, and unpublished results). In the light of the inhibitory effect of MRs on HPA activity which is reflected by studies employing MR antagonists in rats (Spencer et al. 1998) and humans (Dodt et al. 1993; Young et al. 1998) or MR antisense in rats (Reul et al. 1997), the observed upregulation of MR capacity seems to be a first step necessary for the inhibition of hypothalamic CRH neurons. This effect on MR is followed by increased GR capacity (Brady et al. 1991; Seckl and Fink 1992; Reul et al. 1993, 1994).

The physiological significance of MR function is further underscored by studies that showed that acute stress in the hippocampus is associated with increased hippocampal (CA1) MR density and function, an effect that is mediated by $\mathrm{CRH}$ and associated with an increased inhibitory tone on HPA activity (Gesing et al., unpublished results). The MR-upregulating effect of antidepressants and the subsequent reduction of HPA overactivity in depressed patients points toward the importance of appropriate MR function. This is further supported by a clinical trial in which antidepressant response to amitriptyline in major depression was impaired by coadministration of spironolactone, an MR antagonist (Hundt et al., unpublished results, cited in Holsboer 1999).

The effects of antidepressants on GR function have been studied using the transgenic mouse that expresses GR antisense (see Section III). After long-term treatment with moclobemide, a reversible inhibitor of MAO A, these mutated mice not only showed normalized HPA activity but also changes in several tests of anxiety and memory (Montkowski et al. 1995). Some of these behavioral alterations may be explained by the recent electrophysiological observation that in these animals the threshold for induction of hippocampal LTP is shifted towards low stimulation frequencies by long-term treatment with moclobemide (Steckler et al. 2000b).

Because long-term administration of moclobemide suppresses HPA activity and activates cAMP-mediated CREB phosphorylation via PKA, the expression of BDNF may be enhanced and followed by a profound alteration in synaptic efficiency (Korte et al. 1995, 1996; Chen et al. 1999; Kafitz et al. 1999). Furthermore, in these transgenic mice, morphine-induced mesolimbic release of serotonin and dopamine as well as the psychomotor-stimulant effects of morphine were enhanced. This is in accordance with the well-established modulation of these neurotransmitters by GR and their modulation of responses to drugs of abuse. After longterm treatment with moclobemide, these neurochemical and behavioral abnormalities disappeared (Sillaber et al. 1998). In addition, tranylcypromin, an irreversible nonselective MAO-inhibitor, was found to induce the AP-1 complex, probably indicating stimulation of a large number of genes by antidepressants (Hope et al. 1994). As outlined above, AP-1 is negatively modulated by GR, whose function is most likely enhanced by this antidepressant drug. These findings support the notion that antidepressants act by improving the negative feedback capacity of the HPA system at various levels and that the setpoint of the HPA system activity is modified in a way that "buffers" the hormonal response to stressors. This may represent one mechanism by which patients who have recovered from a depressive episode may be protected by long-term antidepressant treatment against further stress-triggered relapses.

\section{CRH Receptor Antagonists}

If one assumes that normalization of an altered HPA setpoint is an essential mechanism for antidepressant drug action, the question arises as to how this goal is achieved. One explanation involves the well founded $\beta$-adrenoceptor desensitization and decrease in cAMPmediated phosphorylation of transcription factors including CREB, following antidepressant treatment. If this effect of antidepressants, which to date has only been demonstrated in vivo for venlafaxin (Rossby et al. 1999), in vitro, however, for several other antidepressants (Schwaninger et al. 1995), is a general phenomenon of antidepressants, then this decreased activation of CREB would result in decreased CRH expression via CRE (see above). An alternative treatment approach would, therefore, be to either suppress the behavioral symptoms of enhanced CRH by CRH receptor antago- 
nist or to block the many untoward effects excessive corticosteroid secretion may have by administration of GR antagonists.

One recently developed pyrazolopyrimidine, R121919, is a compound with high affinity for CRH-R1 that is now clinically tested and appears to not suppress stress-induced HPA response: patients and controls treated with varying dosages of R121919 did not have an impaired CRH-elicited ACTH and cortisol release (Zobel et al. 2000). This is consistent with the selectivity of such compounds for CRH-R1, leaving pituitary CRH-R2 still responsive to CRH challenges, which in conjunction with other ACTH secretagogues such as vasopressin may override the CRH-R1 blockade at corticotrophs. This is in accord with a report by Sánchez et al. (1999), who found that CRH2-R exist at primate corticotrophs. In addition, the possibility exists that the doses used in human studies still leaves sufficient CRH-R1 available for CRH-elicited ACTH response.

The first open label trial with a CRH1-R antagonist observed significant reductions in depression and anxiety scores using both clinician and patient ratings, suggesting that this type of compound may have considerable therapeutical potential. The question of whether CRH-R1 antagonists resolve the entire depressive syndrome or only several stress-related symptoms, such as pathological anxiety, loss of appetite and sexual drive, sleep disturbance, psychomotor and cardiovascular changes, etc. as found in animal experiments, remains to be validated in controlled clinical studies. Another important aspect are the consequences of CRH-R1 antagonist withdrawal. Long-term CRH-R1 antagonist treatment may result in receptor upregulation and enhanced $\mathrm{CRH}$ secretion in a similar way as was seen in CRH-R1 knockout mice where CRH accumulation occurs in all areas in which CRH-R1 is normally expressed, e.g., in the amygdala. After cessation of long-term treatment, patients with depression may have upregulated $\mathrm{CRH}_{1}$ receptors and accumulated ligand $(\mathrm{CRH})$, which together may increase liability for relapse, possibly making tapering of the drug necessary (Zobel et al. 2000).

\section{Cortisol Synthesis Inhibitors}

The other alternative focusses on reduction of cortisol either by cortisol synthesis inhibitors or by blocking their action by antagonizing their effects at receptors and has only been investigated in a small number of studies. Administration of metyrapone results in an inhibition of hydroxylation at position C11 of the steroid molecule, thus preventing synthesis of cortisol and corticosterone. Metyrapone treatment has produced antidepressant-like behavioral changes in two frequently used rodent models for screening antidepressive compounds, the forced swim-test and the olfactory-bulbectomized rat (Healy et al. 1999).
Metyrapone and the antidepressant desimipramine produced similar effects in these models, in agreement with a clinical study by $\mathrm{O}^{\prime} \mathrm{Dwyer}$ and coworkers ( $\mathrm{O}^{\prime} \mathrm{Dw}$ yer et al. 1995), who confirmed the antidepressant potential of metyrapone in a placebo-controlled trial already suggested in numerous exploratory studies. This clinical effect seems to contradict the notion that decreased cortisol-mediated feedback may elicit increased $\mathrm{CRH}$ in all those brain areas where CRH gene expression is negatively controlled by GR. It was hypothesized that such an increase in CRH may either directly or indirectly precipitate some of the cardinal symptoms of depression. However, as discovered in a series of studies by Patchev et al. $(1994,1996,1997)$, the additional bioavailability of non C11-hydroxylated adrenal steroids increases the pool of so-called neuroactive steroids (such as tetrahydro11-deoxy-cortisol or tetrahydro11deoxycorticosterone) which can exert a number of neuroendocrine and behavioral symptoms such as reduction of anxiety-like behavior and suppression of CRH expression. These results indicate that neuroactive steroids may be able to compensate for the loss of corticosterone (or cortisol in humans) following metyrapone. In this context it is of interest that these neuroactive steroids may exert both genomic and nongenomic effects (Rupprecht et al. 1993) and that the concentration of these steroids is modulated by antidepressants in animals and humans (Romeo et al. 1998; Uzunova et al. 1998; Ströhle et al. 2000).

Other strategies comprise treatments with aminogluthetimide, which is a less selective inhibitor of cortisol biosynthesis, and with ketokonazole. Aminogluthetimide blocks $3 \beta$-steroiddehydrogenase and 11ß-hydroxylase. Ketokonazole, in addition to blocking adrenal steroid synthesis, inhibits cytochrome P450-dependent enzymes (11-hydroxylase, 17-hydroxylase, C17,20 lyase) similar to aminogluthetimide and has direct inhibitory effects on other anterior pituitary cells than corticotrophs (Stalla et al. 1989) thus, for example, affecting gonadal steroid secretion. Consistent with predictions from open label studies (e.g., Murphy 1991; Thakore and Dinan 1995), a recent double blind placebo-controlled study suggested that ketokonazole is superior to placebo among hypercortisolemic depressed patients (Wolkowitz et al. 1999). Here again, it is difficult to dissociate the effects of ketokonazole from the effects of other adrenal steroids which are produced at much higher rates because of the enzyme blockade. Interestingly, in the study by Wolkowitz and coworkers (1999) pregnenolone sulfate which is a negative allosteric modulator of the $\mathrm{GABA}_{\mathrm{A}}$ receptor is increased eightfold by ketokonazole. Thus, ketokonazole may exert psychotropic effects through increased pregnenolone which has been reported to improve cognitive impairment in animals (Flood et al. 1995).

Appreciation of studies examining the effects of corticosteroid synthesis inhibitors thus requires recogni- 
tion of the very complex changes in steroid metabolism which may be induced by the applied drugs; these changes can result in a manifold of different psychotropic effects. Controlled studies evaluating the potential benefits of metyrapone either given alone or in combination with standard antidepressants in depression are warranted.

\section{Corticosteroid Receptor Antagonists}

Blockade of corticosteroid receptors as a treatment strategy has been poorly studied due to the lack of specific antagonists. Preliminary results from Murphy et al. (1993) suggested that mifepristone (RU 486) may be a useful treatment approach in major depression. Theoretically, mifepristone may be particularly effective in psychotic depression where the HPA system is most frequently hyperactive and where cortisol induced inhibition of dopamine metabolism may be involved in the pathogenesis of this subtype of depression (Schatzberg et al. 1985). In fact, trimipramin, an effective antidepressant monotherapy of psychotic depression, suppresses hypersecretion of cortisol very effectively (Holsboer-Trachsler et al. 1994; Sonntag et al. 1996).

In contrast to GR antagonism, more substantial data are available for the MR antagonist spironolactone, which if coadministered with the antidepressant amitriptyline impairs antidepressant drug response (Hundt et al., unpublished, cited in Holsboer 1999). The explanation for this finding is related to the studies discussed above, supporting the notion that the first neuroendocrine response to antidepressants is an increase in hippocampal MR, which apparently is required to initiate the cascade that ultimately leads to clinical response (Reul et al. 1993, 1994). Notably, MR agonists enhance hypothalamic CRH release through their hippocampal action. Selective GR antagonists most likely enhance $\mathrm{CRH}$ secretion from the hypothalamus which is in line with data from Tronche and coworkers (1999) where a neuron-specific deletion of the GR led to an increase in CRH and PVN of these mice. In other brain areas, e.g., in those where $\mathrm{CRH}$ is activated by GR, treatment with GR antagonists may repress $\mathrm{CRH}$ gene activity. Clinical trials are therefore needed to clarify the therapeutic potential of GR antagonists in depression and related disorders.

It is not fully clear, however, how disturbed corticosteroid receptor signaling can be influenced therapeutically. Conservatively, administration of a CRH-R1 antagonist is expected to shorten the onset of coadministered antidepressants. Such drugs may also act as antidepressants when administered as monotherapy. Similarly, GR antagonists might not be effective enough as a monotherapy, but they may be a worthwhile adjunct to antidepressants. Whether corticosteroid synthesis inhibitors have therapeutic potential is an open question, since these drugs induce many other psychotropic steroid metabolites. Some studies, however, suggest that metyrapone may taper untoward effects of stress under experimental conditions in rats (Calvo et al. 1998) as well as in patients with cancer (Deguchi et al. 1998).

\section{OUTLOOK}

The examples discussed in this article support the hypothesis that impaired central stress hormone regulation is causally involved in the development and course of depression. In addition, experimental evidence is provided, suggesting that the mechanism of action of antidepressants includes normalization of HPA activity. This hypothesis can now be tested clinically as well as in basic laboratories. While clinical studies are needed to test whether specific intervention at various levels of stress hormone regulation, i.e., CRH-R1 or GR antagonists are equal or superior to current antidepressants, basic studies need to elaborate intracellular signaling and DNA effects of antidepressants and how stress hormones interfere.

The advent of the detailed human genome map in the near future combined with the use of the techniques that allow gene expression profiling on a large scale in a short time offers the possibility to discover novel candidate drug targets. Once identified, the possible relevance of such candidate genes can be verified by generating mouse mutants where the corresponding gene had been inactivated. Only if a relevant phenotype emerges from behavioral screening, a more detailed analysis and the search for molecules that modulate expression of the respective gene or its nuclear effects is warranted.

Techniques that allow large scale analysis of the proteom, and in particular transcription factor activation by phosphorylation in a similar way to that presently used for profiling of gene activation by DNA microarrays still need to be developed. The clinical observations pointing to stress hormone dysregulation causing depression on the one hand and the manifold cellular and nuclear effects of hormone-activated GR and MR on the other, predicts that CR-regulated genes and derived proteins may ultimately be identified as optimal drug targets for depression and possibly other stressrelated disorders. Drugs that will emerge from new strategies in biomedicine are likely to be more selectively targeted to specific elements of the HPA system than standard antidepressants. These new drugs promise to act much faster, however only in cases where the central stress hormone system is defunct.

Because these changes in stress-related neuropeptide and corticosteroid secretion are not uniform in the CNS, but subjected to a neuroanatomical microheterogeneity, i.e., may not affect all brain areas in the same way, it seems important to keep in mind that peripheral mea- 
sures of the pituitary-adrenocortical activity do not necessarily reflect alterations in the release of CR-regulated neuropeptides such as $\mathrm{CRH}$, e.g., in the central amygdala, locus coeruleus, or prefrontal cortex. Therefore, the challenge for clinical research is to develop laboratory tests that allow to specifically identify those patients who may potentially benefit from a therapeutic strategy that specifically targets the central stress hormone system.

\section{REFERENCES}

Alléra A, Wildt L (1992): Glucocorticoid-recognizing and -effector sites in rat liver plasma membrane. Kinetics of corticosterone uptake by isolated membrane vesicles. I. Binding and transport. J Steroid Biochem Mol Biol 42:737-756

Almeida OF, Conde GL, Crochemore C, Demeneix BA, Fischer D, Hassan AH, Meyer M, Holsboer F, Michaelidis TM (2000): Subtle shifts in the ratio between pro- and antiapoptotic molecules after activation of corticosteroid receptors decide neuronal fate. FASEB J 14:779-790

Auphan N, Didonato JA, Rosette C, Helmberg A, Karin M (1995): Immunosuppression by glucocorticoids: Inhibition of NF- $\kappa$ B activity through induction of $1 \kappa B$ synthesis. Science 270:286-290

Bale TI, Gontarino A, Smith GW, Chan R, Gold LH, Sawchenko PE, Koob GF, Vale WW, Lee K-F (2000): Mice deficient for corticotropin-releasing hormone receptor-2 display anxiety-like behaviour and are hypersensitive to stress. Nature Genet 24:410-414

Bamberger CM, Bamberger AM, DeCastro M, Chrousos GP (1995): Glucocorticoid receptor beta, a potential endogenous inhibitor of glucocorticoid action in humans. J Clin Invest 95:2435-2441

Barden N, Stec I, Montkowski A, Holsboer F, Reul JMHM (1997): Endocrine profile and neuroendocrine challenge tests in transgenic mice expressing antisense RNA against the glucocorticoid receptor. Neuroendocrinology 66:212-220

Beato M, Herrlich P, Schütz G (1995): Steroid hormone receptors: Many actors in search of a plot. Cell 83:851-857

Behan DJP, Heinrichs SC, Troncoso JC, Liu XJ, Kawas CH, Ling N, De Souza EB (1995): Displacement of corticotropin releasing factor from its binding protein as a possible treatment for Alzheimer's disease. Nature 378:284-287

Behl C, Lezoualc'h F, Trapp T, Widmann M, Skutella T, Holsboer F (1997): Glucocorticoids enhance oxidative stress-induced cell death in hippocampal neurons in vitro. Endocrinology 138:101-106

Berger S, Bleich M, Schmid W, Cole TJ, Peters J, Watanabe HWK, Warth R, Greger R, Schütz G (1998): Mineralocorticoid receptor knockout mice: Pathophysiology of sodium metabolism. Proc Natl Acad Sci USA 95:9424-9429

Bleuler M (1919): The Internal Secretions and the Nervous System. (Nervous and Mental Disease Monograph Series, No. 30.) New York, Nervous and Mental Disease Publ Comp
Brady LS, Whitfield HJ Jr, Fox RJ, Gold PW, Herkenham M (1991): Long-term antidepressant administration alters corticotropin-releasing hormone, tyrosine hydroxylase, and mineralocorticoid receptor gene expression in rat brain. Therapeutic implications. J Clin Invest 87:831-837

Bremner J, Southwick S, Charney D (1999): The neurobiology of post-traumatic stress disorder: An integration of animal and human research. In Saigh $\mathrm{P}$, Bremner J (eds), Post-traumatic Stress Disorder: A Comprehensive Text. Needham Heights, MA, Allyn \& Cacon, pp 103143

Bremner JD, Narayan M, Anderson ER, Staib LH, Miller HL, Charney DS (2000): Hippocampal volume reduction in major depression. Am J Psychiatry 157:115-117

Burrows HL, Nakajima M, Lesh JS, Goosens KA, Samuelson LC, Inui A, Camper SA, Seasholtz AF (1998): Excess corticotropin-releasing hormone-binding protein in the hypothalamic-pituitary-adrenal axis in transgenic mice. J Clin Invest 101:1439-1447

Caldenhoven E, Liden J, Wissink S, Van de Stolpe A, Raaijmakers J, Okret S, Gustafsson J-A, Van der Saag PT (1995): Negative crosstalk between RelA and the glucocorticoid receptor: A possible mechanism for the antiinflammatory action of glucocorticoids. Mol Endocrinol 9:401-412

Calvo N, Martijena ID, Molina VA, Volosin M (1998): Metyrapone pretreatment prevents the behavioral and neurochemical sequelae induced by stress. Brain Res 800:227-235

Carroll J (1982): Clinical applications of the dexamethasone suppression test for endogenous depression. Pharmacopsychiatry 15:19-24

Chalmers DT, Lovenberg TW, De Souza EB (1995): Localization of novel corticotropin-releasing factor receptor (CRF2) mRNA expression to specific subcortical nuclei in rat brain: Comparison with CRF1 receptor mRNA expression. J Neurosci 15:6340-6350

Chen G, Kolbeck R, Barde Y-A, Bonhoeffer T, Kossel A (1999): Relative contribution of endogenous neurotrophins in hippocampal long-term potentiation. J Neurosci 19:7983-7990

Chrousos GP, Renquist D, Brandon D, Eil C, Pugeat M, Vigersky R, Cutler GB Jr, Loriaux DL, Lipsett MB (1982): Glucocorticoid hormone resistance during primate evolution: receptor-mediated mechanisms. Proc Natl Acad Sci USA 79:2036-2040

Cole TJ (1996): Steroid receptor knockouts. Curr Opin Endocrinol Diabet 3:363-368

Coplan JD, Andrews MW, Rosenblum LA, Owens MJ, Friedman S, Gorman JM, Nemeroff CB (1996): Persistent elevations of cerebrospinal fluid concentrations of corticotropin-releasing factor in adult non-human primates exposed to early-life stressors: Implications for the pathophysiology of mood and anxiety disorders. Proc Natl Acad Sci USA 93:1619-1623

Coste SC, Kesterson RA, Heldwein KA, Stevens SL, Heard AD, Hollis JH, Murray SE, Hill JK, Pantely GA, Hohimer AR, Hatton DC, Phillips TJ, Finn DA, Low MJ, Rittenberg MB, Stenzel P, Stenzel-Poore MP (2000): Abnormal adaptations to stress and impaired cardiovascular function in mice lacking corticotropin-releasing hormone receptor-2. Nature Genet 24:403-409 
de Bellis MD, Gold, PW, Geracioti TD Jr, Listwak SJ, Kling MA (1993): Association of fluoxetine treatment with reductions in CSF concentrations of corticotropinreleasing hormone and arginine vasopressin in patients with major depression. Am J Psychiatry 150:656-657

de Kloet ER, Vreugdenhil E, Oitzl MS, Joëls M (1998): Brain corticosteroid receptor balance in health and disease. Endocrinol Rev 19:269-301

de Kloet ER, Oitzl MS, Joëls M (1999): Stress and cognition: Are corticosteroids good or bad guys? Trends Neurosci 22:422-426

de Quervain DJ-F, Roozendaal B, McGaugh JL (1998): Stress and glucocorticoids impair retrieval of long-term spatial memory. Nature 394:787-790

Deguchi M, Yoshiaki I, Matsukawa S, Yamaguchi A, Nakagawara G (1998): Useful of metyrapone treatment to suppress cancer metastasis facilitated by surgical stress. Surgery 123:440-449

Delgado PL, Charney DS, Price LH, Aghajanian GK, Landis H, Heninger GR (1990): Serotonin function and the mechanism of antidepressant action: Reversal of antidepressant-induced remission by rapid depletion of plasma tryptophan. Arch Gen Psychiatry 47:411-418

Delgado PL, Price LH, Heninger GR, Charney DS (1992): Neurochemistry of affective disorders. In Paykel ES (ed), Handbook of Affective Disorders. New York, NY, Churchill Livingstone, pp 219-253

Detera-Wadleigh SD, Berrettini WH, Goldin LR, Martinez M, Hsieh WT, Hoehe MR, Encio IJ, Coffman D, Rollins DY, Muniec D (1992): A systematic search for a bipolar predisposing locus on chromosome 5. Neuropsychopharmacology 6:219-229

Dijkstra I, Tilders FJH, Aguilera G, Kiss A, Rabandan-Diehl C, Barden N, Karanth S, Holsboer F, Reul JMHM (1998): Reduced activity of hypothalamic corticotropin-releasing hormone neurons in transgenic mice with impaired glucocorticoid receptor function. J Neurosci 18:3909-3918

Dodt C, Kern W, Fehm HL, Born J (1993): Antimineralocorticoid canrenoate enhances secretory activity of the hypothalamus-pituitary-adrenocortical (HPA) axis in humans. Neuroendocrinology 58:570-574

Drouin J, Sun YL, Chamberland M, Gauthier Y, De Lean A, Nemer M, Schmidt TJ (1993): Novel glucocorticoid receptor complex with DNA element of the hormonerepressed POMC gene. EMBO J 12:145-156

Drouin J, Maira M, Philips A (1998): Novel mechanism of action for Nur77 and antagonism by glucocorticoids: A convergent mechanism for $\mathrm{CRH}$ activation and glucocorticoid repression of POMC gene transcription. J Steroid Biochem Mol Biol 65:59-63

Duman RS, Heninger GR, Nestler EJ (1997): A molecular and cellular theory of depression. Arch Gen Psychiatry 54:597-606

Eiring A, Sulser F (1997): An increased synaptic availability of norepinephrine is not essential for antidepressant induced increases in hippocampal GR mRNA. J Neural Transm 104:1255-1258

Erkut ZA, Pool C, Swaab DF (1998): Glucocorticoids suppress corticotropin-releasing hormone and vasopessin expression in human hypothalamic neurons. J Clin Endocrinol Metab 83:2066-2073
Flood JF, Morley JE, Roberts E (1995): Pregnenolone sulfate enhances post-training memory processes when injected in very low doses into limbic system structures; the amygdala is by far the most sensitive. Proc Natl Acad Sci USA 92:10806-10810

Freedman LP (1999): Increasing the complexity of coactivation in nuclear receptor signaling. Cell 97:5-8

Gold PW, Loriaux DL, Roy A, Kling MA, Calabrese JR, Kellner CH, Nieman LK, Post RM, Pickar D, Gallucci W, Avgerinos P, Paul S, Oldfield EH, Cutler GB Jr, Chrousos GP (1986): Responses to corticotropin-releasing hormone in the hypoercortisolism of depression and Cushing's disease. N Engl J Med 314:1329-1335

Gould E, McEwen BS, Tanapat P, Galea LAM, Fuchs E (1997): Neurogenesis in the dentate gyrus of the adult tree shrew is regulated by psychosocial stress and NMDA receptor activation. J Neurosci 17:2492-2498

Gray TS, Bingaman EW (1996): The amygdala: Corticotropin-releasing factor, steroids, and stress. Critical Rev Neurobiol 10:155-168

Greden F, Gardner R, King D, Grunhaus L, Carroll J, Kronfol Z (1983): Dexamethasone suppression test in antidepressant treatment of melancholia. Arch Gen Psychiatry 40:493-500

Hassan AHS, von Rosenstiel P, Patchev VK, Holsboer F, Almeida OFX (1996): Exacerbation of apoptosis in the dentate gyrus of the aged rat by dexamethasone and the protective role of corticosterone. Exp Neurol 140:43-52

Hassan AHS, Patchev VK, von Rosenstiel P, Holsboer F, Almeida OFX (1999): Plasticity of hippocampal corticosteroid receptors during aging in the rat. FASEB J 13:115-122

Healy DG, Harkin A, Cryan JF, Kelly JP, Leonard BE (1999): Metyrapone displays antidepressant-like properties in preclinical paradigms. Psychopharmacology 145:303-308

Heck S, Kullmann M, Gast A, Ponta H, Rahmsdorf HJ, Herrlich P, Cato ACB (1994): A distinct modulating domain in glucocorticoid receptor monomers in the repression of activity of the transcription factor AP-1. EMBO J 13:4087-4095

Heim C, Newport DJ, Heit S, Graham YP, Wilcox M, Bonsall R, Miller AH, Nemeroff CB (2000): Increased pituitaryadrenal and autonomic responses to stress in adult women after sexual and physical abuse in childhood. JAMA, In press

Heinrichs SC, Lapsansky J, Lovenberg TW, De Souza EB, Chalmers DT (1997): Corticotropin-releasing factor CRF1, but not CRF2 receptors mediate anxiogenic-like behavior. Regul Peptides 71:15-21

Heuser I, Yassouridis A, Holsboer F (1994): The combined dexamethasone/CRH test: A refined laboratory test for psychiatric disorders. J Psychiatric Res 28:341-356

Heuser IJE, Schweiger U, Gotthardt U, Schmider J, Lammers CH, Dettling M, Yassouridis A, Holsboer F (1996): Pituitary-adrenal-system regulation and psychopathology during amitriptyline treatment in elderly depressed patients and in normal comparison subjects. Am J Psychiatry 153:93-99

Holsboer F (1999): The rationale for corticotropin-releasing hormone receptor (CRH-R) antagonists to treat depression and anxiety. J Psychiatric Res 33:181-214 
Holsboer F, Barden N (1996): Antidepressants and HPA regulation. Endocrinol Rev 17:187-203

Holsboer F, Liebl R, Hofschuster E (1982): Repeated dexamethasone suppression test during depressive illness. Normalization of test result compared with clinical improvement. J Affect Disord 4:93-101

Holsboer F, Gerken A, Von Bardeleben U, Grimm W, Beyer H, Müller OA, Stalla GK (1986): Human corticotropinreleasing hormone $(\mathrm{CRH})$ in patients with depression, alcoholism and panic disorder. Biol Psychiatry 21:601611

Holsboer F, Von Bardeleben U, Wiedemann K, Müller OA, Stalla GK (1987): Serial assessment of corticotropinreleasing hormone response after dexamethasone in depression-implications for pathophysiology of DST nonsuppression. Biol Psychiatry 22:228-234

Holsboer F, Spengler D, Heuser I (1992): The role of corticotropin-releasing hormone in the pathogenesis of Cushing's disease, anorexia nervosa, alcoholism, affective disorders and dementia. Prog Brain Res 93:385-417

Holsboer F, Lauer CJ, Schreiber W, Krieg J-C. (1995): Altered hypothalamic-pituitary-adrenocortical regulation in healthy subjects at high familial risk for affective disorders. Neuroendocrinology 62:340-347

Holsboer-Trachsler E, Hemmeter U, Hatzinger M, Seifritz E, Gerhard U, Hobi V (1994): Sleep deprivation and bright light as potential augmenters of antidepressant drug treatment-neurobiological and psychometric assessment of course. J Psychiatric Res 28:381-399

Hope BT, Nye HE, Kelz MB, Self DW, Iadarola MJ, Nakabeppu Y, Duman RS, Nestler EJ (1994): Induction of a long-lasting AP-1 complex composed of altered Fos-like proteins in brain by chronic cocaine and other chronic treatments. Neuron 13:1235-1244

Huizenga NATM, Koper JW, de Lange P, Pols HAP, de Jong FH, Stolk RP, Grobbee DE, Lamberts SWJ (1998): Interperson variability, but intraperson reproducibililty of baseline cortisol concentrations and its relation to the feedback sensitivity of the hypothalamo-pituitary-adrenal axis to low dose dexamethasone. J Clin Endocrinol Metab 83:47-54

Joëls M, de Kloet ER (1992): Control of neuronal excitability by corticosteroid hormones. Trends Neurosci 15:25-30

Kafitz KW, Rose CR, Thoenen H, Konnerth A (1999): Neurotrophin-evoked rapid excitation through TrkB receptors. Nature 401:918-921

Kanelakis KC, Morishima Y, Dittmar KD, Galigniana MD, Takayama S, Reed JC, Pratt WB (1999): Differential effects of the hsp70-binding protein BAG-1 on glucocorticoid receptor folding by the hsp90-based chaperone machinery. J Biol Chem 274:34134-34140

Kang KI, Meng X, Devin-Leclerc J, Bouhouche I, Chadli A, Cadepond F, Baulieu E-E, Catelli M-G (1999): The molecular chaperone hsp90 can negatively regulate the activity of a glucocorticosteroid-dependent promoter. Proc Natl Acad Sci USA 96:1439-1444

Karanth S, Linthorst ACE, Stalla GK, Barden N, Holsboer F, Reul JMHM (1997): Hypothalamic-pituitary-adrenocortical axis changes in a transgenic mouse with impaired glucocorticoid receptor function. Endocrinology 138:34763485
Karolyi IJ, Burrows HL, Ramesh TM, Nakajima M, Lesh JS, Seong E, Camper SA, Seasholtz AF (1999): Altered anxiety and weight gain in corticotropin-releasing hormone-binding protein-deficient mice. Proc Natl Acad Sci USA 96:11595-11600

Kendler KS, Karkowski LM, Prescott CA (1999): Causal relationship between stressful life events and the onset of major depression. Am J Psychiatry 156:837-841

Kerr DS, Campell LW, Applegate MD, Brodish A, Landfield PW (1991): Chronic stress-induced acceleration of electrophysiologic and morphometric biomarkers of hippocampal aging. J Neurosci 11:1316-1324

Kishimoto T, Radulovic J, Radulovic M, Lin CR, Schrick C, Hooshmand F, Hermanson O, Rosenfeld MG, Spiess J (2000): Deletion of Crhr2 reveals an anxiolytic role for corticotropin-releasing hormone receptor-2. Nature Genet 24:415-419

Koper JW, Stolk RP, de Lange P, Huizenga NATM, Molijn G-J, Pols HAP, Grobbee DE, Karl M, de Jong FH, Brinkmann AO, Lamberts SWJ (1997): Lack of association between five polymorphisms in the human glucocorticoid receptor gene and glucocorticoid resistance. Human Genet 99:663-668

Korte M, Carroll P, Wolff E, Brem G, Thoenen H, Bonhoeffer $T$ (1995): Hippocampal long-term potentiation is impaired in mice lacking brain-derived neurotrophic factor. Proc Natl Acad Sci USA 92:8856-8860

Korte M, Griesbeck O, Gravel C, Carroll P, Staiger V, Thoenen H, Bonhoeffer T (1996): Virus-mediated gene transfer into hippocampal CA1 region restores long-term potentiation in brain-derived neurotrophic factor mutant mice. Proc Natl Acad Sci USA 93:12547-12552

Lackner C, Daufeldt S, Wildt L, Alléra A (1998): Glucocorticoid-recognizing and -effector sites in rat liver plasma membrane. Kinetics of corticosterone uptake by isolated membrane vesicles. III. Specificity and stereospecificity. J Steroid Biochem Mol Biol 64:69-82

Ladd CO, Owens MJ, Nemeroff CB (1996): Persistent changes in corticotropin-releasing factor neuronal systems induced by maternal deprivation. Endocrinology 137:1212-1218

Lamberts SWJ, Koper JW, Biemond P, den Holder FH, de Jong FH (1992): Cortisol receptor resistance: The variability of its clinical presentation and response to treatment. J Clin Endocrinol Metab 74:313-321

Lamberts SWJ, Huizenga ATM, de Lange P, de Jong FH, Koper JW (1996): Clinical aspects of glucocorticoid sensitivity. Steroids 61:157-160

Landfield PW, Baskin RK, Pitler TA (1981): Brain aging correlates: Retardation by hormonal-pharmacological treatments. Science 214:581-584

Lanz RB, McKenna NJ, Onate SA, Albrecht U, Wong J, Tsai SY, Tsai M-J, O'Malley BW (1999): A steroid receptor coactivator, SRA, functions as an RNA and is present in an SRC-1 complex. Cell 97:17-274

Lauer CJ, Schreiber W, Modell S, Holsboer F, Krieg J-C (1998): The Munich vulnerability study of affective disorders. J Psychiatric Res 32:393-401

Legradi G, Holzer D, Kapcala LP, Lechan RM (1997): Glucocorticoids inhibit stress-induced phosphorylation of CREB in corticotropin-releasing hormone neurons of 
the hypothalamic paraventricular nucleus. Neuroendocrinology 66:86-97

Leverenz JB, Wilkinson CW, Wamble M, Corbin S, Grabber JE, Raskind MA, Peskind ER (1999): Effect of chronic high-dose exogenous cortisol on hippocampal neuronal number in aged nonhuman primates. J Neurosci 19:2356-2361

Levine S, Mullins RF (1966): Hormonal influences on brain organization in infant rats. Science 152:1585-1592

Liebsch G, Landgraf R, Gerstberger R, Probst JC, Wotjak CT, Engelmann M, Holsboer F, Montkowski A (1995): Chronic infusion of a $\mathrm{CRH}_{1}$ receptor antisense oligodeoxynucleotide into the central nucleus of the amygdala reduced anxiety-related behavior in socially defeated rats. Regul Peptides 59:229-239

Liebsch G, Landgraf R, Engelmann M, Lörscher P, Holsboer $F$ (1999): Differential behavioural effects of chronic infusion of $\mathrm{CRH}_{1}$ and $\mathrm{CRH}_{2}$ receptor antisense oligodeoxynucleotides into the rat brain. J Psychiatric Res 33:153163

Linthorst ACE, Flachskamm C, Hopkins SJ, Hoadley ME, Labeur MS, Holsboer F, Reul JMHM (1997): Long-term intracerebroventricular infusion of corticotropin-releasing hormone alters neuroendocrine, neurochemical, autonomic, behavioral, and cytokine responses to a systemic inflammatory challenge. J. Neurosci 17:4448-4460

Linthorst ACE, Karanth S, Barden N, Holsboer F, Reul JMHM (1999): Impaired glucocorticoid receptor function evolves in aberrant physiological responses to bacterial endotoxin. Eur J Neurosci 11:178-186

Linthorst ACE, Flachskamm C, Barden N, Holsboer F, Reul JMHM (2000): Glucocorticoid receptor impairment alters CNS responses to a psychological stressor: An in vitro microdialysis study in transgenic mice. Eur J Neurosci 12:283-291

Liu J, DeFranco DB (1999): Chromatin recycling of glucocorticoid receptors: Implications for multiple roles of heat shock protein 90. Mol Endocrinol 13:355-365

Lôo H, Saiz-Ruiz J, Costa e Silva JA, Ansseau M, Herrington R, Vaz-Serra A, Dilling H, de Risio S (1999): Efficacy and safety of tianeptine in the treatment of depressive disorders in comparison with fluoxetine. J Affect Disord 56:109-118

Lupien SJ, de Leon M, de Santi S, Convit A, Tarshish C, Nair NPV, Thakur M, McEwen BS, Hauger RL, Meaney MJ (1998): Cortisol levels during human aging predict hippocampal atrophy and memory deficits. Nature Neurosci 1:69-73

Magariños AM, McEwen BS, Flügge G, Fuchs E (1996): Chronic psychosocial stress causes apical dendritic atrophy of hippocampal CA3 pyramidal neurons in subordinate tree shrews. J Neurosci 16:3534-3540

Magariños AM, Verdugo JM, McEwen BS (1997): Chronic stress alters synaptic terminal structure in hippocampus. Proc Natl Acad Sci USA 94:14002-14008

Malkoski SM, Handanos CM, Dron RI (1997): Localization of a negative glucocorticoid response element of the human corticotropin releasing hormone gene. Mol Cell Endocrinol 127:189-199

Malkoski SP, Dorin RI (1999): Composite glucocorticoid regulation at a functionally defined negative glucocorticoid response element of the human corticotropin-releasing hormone gene. Mol Endocrinol 13:1629-1644

Mangelsdorf DJ, Thummel C, Beato M, Herrlich P, Schütz G, Umesono K, Blumberg B, Kastner P, Mark M, Chambon P, Evans RM (1995): The nuclear receptor superfamily: The second decade. Cell 83:835-839

McEwen BS, Angulo J, Cameron H, Chao HM, Daniels D, Gannon MN, Gould E, Mendelson S, Sakai R, Spencer R, Woolley C (1992): Paradoxical effects of adrenal steroids on the brain: Protection versus degeneration. Biol Psychiatry 31:177-199

Meijer OC, Cole TJ, Schmid W, Schütz G, Joëls M, De Kloet ER (1997): Regulation of hippocampal 5-HT1A receptor mRNA and binding in transgenic mice with a targeted disruption of the glucocorticoid receptor. Mol Brain Res 46:290-296

Meijer OC, de Lange ECM, Breimer DD, de Boer AG, Workel JO, De Kloet ER (1998): Penetration of dexamethasone into brain glucocorticoid targets is enhanced in mdr1AP-glycoprotein knockout mice. Endocrinology 139:1789-1793

Modell S, Yassouridis A, Huber J, Holsboer F (1997): Corticosteroid receptor function is decreased in depressed patients. Neuroendocrinology 65:216-222

Modell S, Lauer CJ, Schreiber W, Huber J, Krieg J-C, Holsboer F (1998): Hormonal response pattern in the combined DEX-CRH test is stable over time in subjects at high familial risk for affective disorders. Neuropsychopharmacology 18:253-262

Montkowski A, Barden N, Wotjak C, Stec I, Ganster J, Meaney M, Engelmann M, Reul JMHM, Landgraf R, Holsboer F (1995): Long-term antidepressant treatment reduces behavioural deficits in transgenic mice with impaired glucocorticoid receptor function. J Neuroendocrinol 7:841-845

Morissette J, Villeneuve A, Lordeleau L, Rochette D, Laberge C, Gagné B, Laprise C, Bouchard G, Plante M, Gobeil L, Shink E, Weissenbach J, Barden N (1999): Genome-wide search for linkage of bipolar affective disorders in a very large pedigree derived from a homogeneous population in Quebec points to a locus of major effect on chromosome 12q23-q24. Am J Med Genet 88:567-587

Müller MB, Lucassen PJ, Yassouridis A, Hoogendijk WJG, Holsboer F, Swaab DE (1998): The human hippocampus in major depression or following administration of glucocorticoids: No evidence for major structural alterations. Soc Neurosci Abstr 24:990

Murphy BEP (1991): Treatment of major depression with steroid suppressive drugs. J Steroid Biochem Mol Biol 39:239-244

Murphy BEP, Filipini D, Ghadirian AM (1993): Possible use of glucocorticoid receptor antagonists in the treatment of major depression: Preliminary results using RU 486. J Psychiatry Neurosci 18:209-213

Murphy EP, Conneely OM (1997): Neuroendocrine regulation of the hypothalamic pituitary adrenal axis by the nurr1/nur77 subfamily of nuclear receptors. Mol Endocrinology 11:39-47

Nelson MD, Saykin AJ, Flashman LA, Riordan HJ (1998): Hippocampal volume reduction in schizophrenia as assessed by magnetic resonance imaging. A meta-analytic study. Arch Gen Psychiatry 55:433-440 
Nemeroff CB, Widerlov E, Bissette G, Walleus H, Karlsson I, Eklund K, Kilts DC, Loosen PT, Vale W (1984): Elevated concentrations of CSF corticotropin-releasing factor-like immunoreactivity in depressed patients. Science 226:1342-1344

Nemeroff CB, Owens MJ, Bissette G, Andorn AC, Stanley M (1988): Reduced corticotropin releasing factor binding sites in the frontal cortex of suicide victims. Arch Gen Psychiatry 45:377-379

Newcomer JW, Selke G, Melson AK, Hershey T, Craft S, Richards K, Alderson AL (1999): Decreased memory performance in healthy humans induced by stress-level cortisol treatment. Arch Gen Psychiatry 56:527-533

Nollen EAA, Brunsting JF, Song J, Kampinga HH, Morimoto RI (2000): Bag1 functions in vivo as a negative regulator of hsp70 chaperone activity. Mol Cell Biol 20:1083-1088

O’Dwyer AM, Lightman SL, Marks M, Checkley SA (1995): Treatment of major depression with metyrapone and hydrocortisone. J Affect Disord 33:123-128

Oitzl MS, Fluttert M, De Kloet ER (1994): The effect of corticosterone on reacitivity to spatial novelty is mediated by central mineralocorticosteroid receptors. Eur J Neurosci 6:1072-1079

Orchinik M, Murrey TF, Moore FL (1991): A corticosteroid receptor in neuronal membranes. Science 252:1848-1851

Owens MJ, Nemeroff CB (1991): Physiology and pharmacology of corticotropin-releasing factor. Pharmacol Rev 43:425-473

Pariante CM, Pearce BD, Pisell TL, Owens MJ, Miller AH (1997): Steroid-independent translocation of the glucocorticoid receptor by the antidepressant desipramine. Mol Pharmacol 52:571-581

Patchev VK, Shoaib M, Holsboer F, Almeida OFX (1994): The neurosteroid tetrahydroprogesterone counteracts corticotropin-releasing hormone-induced anxiety and alters the release and gene expression of corticotropinreleasing hormone in the rat hypothalamus. Neuroscience 62:265-271

Patchev VK, Hassan AHS, Holsboer F, Almeida OFX (1996): The neurosteroid tetrahydroprogesterone attenuates the endocrine response to stress and exerts glucocorticoidlike effects on vasopressin gene transcription in the rat hypothalamus. Neuropsychopharmacology 15:533-540

Patchev VK, Montkowski A, Rouskova D, Koranyi L, Holsboer F, Almeida OFX (1997): Neonatal treatment of rats with the neuroactive steroid tetrahydrodeoxycorticosterone (THDOC) abolishes the behavioral and neuroendocrine consequences of adverse early life events. J Clin Invest 99:962-966

Paul SM, Purdy RH (1992): Neuroactive steroids. FASEB J 6:2311-2322

Pepin MC, Pothier F, Barden N (1992): Impaired type II glucocorticoid-receptor function in mice bearing antisense RNA transgene. Nature 355:725-728

Pfahl M (1993): Nuclear receptor/AP-1 interaction. Endocrinol Rev 14:651-658

Philips A, Maira M, Mullick A, Chamberland M, Lesage S, Hugo P, Drouin J (1997): Antagonism between Nur77 and glucocorticoid receptor for control of transcription. Mol Cell Biol 17:5952-5959
Plotsky P, Meaney M (1993): Early, postnatal experience alters hypothalamic corticotropin-releasing factor (CRF) mRNA, median eminence CRF-content and stressinduced release in adult rats. Mol Brain Res 18:195-200

Potter E, Behan DP, Fischer WH, Linton EA, Lowry PJ, Vale WW (1991): Cloning and characterization of the cDNAs for human and rat corticotropin releasing factor-binding proteins. Nature 349:423-426

Pratt WB, Dittmar KD (1998): Studies with purified chaperones advance the understanding of the mechanism of glucocorticoid receptor-hsp90 heterocomplex assembly. TEM 9:244-252

Purba JS, Hoogendijk WJG, Hofman MA, Swaab DF (1996): Increased number of vasopressin- and oxytocinexpressing neurons in the paraventricular nucleus of the hypothalamus in depression. Arch Gen Psychiatry 53:137-143

Raadsheer FC, Hoogendijk WJG, Stam FC, Tilders FHJ, Swaab DF (1994): Increased numbers of corticotropinreleasing hormone expressing neurons in the hypothalamic paraventricular nucleus of depressed patients. Neuroendocrinology 60:433-436

Radulovic J, Rühmann A, Liepold T, Spiess J (1999): Modulation of learning and anxiety by corticotropin-releasing factor (CRF) and stress: Differential roles of CRF receptors 1 and 2. J Neurosci 19:5016-5025

Rajkowska G, Miguel-Hidalgo JJ, Wei J, Dilley G, Pittman SD, Meltzer HY, Overholser JC, Roth BL, Stockmeier CA (1999): Morphometric evidence for neuronal and glial prefrontal cell pathology in major depression. Biol Psychiatry 45:1085-1098

Reichardt HM, Kaestner KH, Tuckermann J, Kretz O, Wessely O, Bock R, Gass P, Schmid W, Herrlich P, Angel P, Schütz G (1998): DNA binding of the glucocorticoid receptor is not essential for survival. Cell 93:531-541

Reynolds PD, Ruan Y, Smith DF, Scammell JG (1999): Glucocorticoid resistance in the squirrel monkeys is associated with overexpression of the immunophilin FKBP51. J Clin Endocrinol Metab 84:663-669

Reul JMHM, Stec I, Söder M, Holsboer F (1993): Chronic treatment of rats with the antidepressant amitriptyline attenuates the activity of the hypothalamic-pituitaryadrenocortical system. Endocrinology 133:312-320

Reul JMHM, Labeur MS, Grigoriadis DE, De Souza EB, Holsboer F (1994): Hypothalamic-pituitary-adrenocortical axis changes in the rat after long-term treatment with the reversible monoamine oxidase-A inhibitor moclobemide. Neuroendocrinology 60:509-519

Reul JMHM, Probst JC, Skutella T, Hirschmann M, Stec IS, Montkowski A, Landgraf R, Holsboer F (1997): Increased stress-induced adrenocorticotropin response after long-term intracerebroventricular treatment of rats with antisense mineralocorticoid receptor oligodeoxynucleotides. Neuroendocrinology 65:189-199

Rochford J, Beaulieu S, Rousse I, Glowa J, Barden N (1997): Behavioral reactivity to aversive stimuli in a transgenic mouse model of impaired glucocorticoid (type II) receptor function: Effects of diazepam and FG-7142. Psychopharmacology 132:145-152

Romeo E, Ströhle A, Spalletta G, di Michele F, Hermann B, Holsboer F, Pasini A, Rupprecht R (1998): Effects of 
antidepressant treatment on neuroactive steroids in major depression. Am J Psychiatry 155:910-913

Roozendaal B, Nguyen BT, Power AE, McGaugh JL (1999): Basolateral amygdala noradrenergic influence enables enhancement of memory consolidation induced by hippocampal glucocorticoid receptor activation. Proc Natl Acad Sci USA 96:11642-11647

Rossby SP, Nalepa I, Huang M, Burt A, Perrin C, Schmidt DE, Sulser F (1995): Norepinephrine-independent regulation of GRII mRNA in vivo by a tricyclic antidepressant. Brain Res 687:79-82

Rossby SP, Manier DH, Liang S, Nalepa I, Sulser F (1999): Pharmacological actions of the antidepressant venlafaxine beyond aminergic receptors. Intl J Neuropsychopharmacol 2:1-8

Rousse I, Beaulieu S, Rowe W, Meaney MJ, Barden N, Rochford J (1997): Spatial memory in transgenic mice with impaired glucocorticoid receptor function. NeuroReport 8:841-845

Rubin RT, Poland RE, Lesser IM, Winston RA, Blodgett ALN (1987): Neuroendocrine aspects of primary endogenous depression. Arch Gen Psychiatry 44:328-336

Rupprecht R, Holsboer F (1999): Neuroactive steroids: Mechanisms of action and neuropsychopharmacological perspectives. Trends Neurosci 22:410-416

Rupprecht R, Reul JMHM, Trapp T, van Steensel B, Wetzel C, Zieglgänsberger W, Damm K, Holsboer F (1993): Progesterone receptor mediated effects of neuroactive steroids. Neuron 11:523-530

Rybakowski JK, Twardowska K (1999): The dexamethasone/corticotropin-releasing hormone test in depression in bipolar and unipolar affective illness. J Psychiatric Res 33:363-370

Sánchez MM, Young LJ, Plotsky PM, Insel TR (1999): Autoradiographic and in situ hybridization localization of corticotropin-releasing factor 1 and 2 receptors in nonhuman primate brain. J Comp Neurol 408:365-377

Sánchez MM, Young LJ, Plotsky PM, Insel TR (2000): Distribution of corticosteroid receptors in the rhesus brain: Relative absence of glucocorticoid receptors in the hippocampal formation. J Neuroscience 20:4657-4668

Sapolsky RM (1992): Stress, the Aging Brain and the Mechanism of Neuron Death. London, MIT Press

Schatzberg AF, Rothschild AJ, Langlais PJ, Bird ED, Cole JO (1985): A corticosteroid/dopamine hypothesis for psychotic depression and related states. J Psychiatric Res 19:57-64

Schinkel AH, Wagenaar E, Van Deemter L, Mol CAAM, Borst P (1995): Absence of the mdrla P-glycoprotein in mice affects tissue distribution and pharmacokinetics of dexamethasone, digoxin, and cyclosporin A. J Clin Invest 96:1698-1705

Schneikert J, Hübner S, Martin E, Cato ACB (1999): A nuclear action of the eukaryotic cochaperone RAP46 in downregulation of glucocorticoid receptor activity. J Cell Biol 146:929-940

Schulkin J, Gold PW, McEwen BS (1998): Induction of corticotropin-releasing hormone gene expression by glucocorticoids: Implication for understanding the states of fear and anxiety and allostatic load. Psychoneuroendocrinology 23:219-243

Schwaninger M, Schoel C, Blume R, Rossig L, Knepel W (1995): Inhibition by antidepressant drugs of cyclic AMP response element-binding protein/cyclic AMP response element-directed gene transcription. Mol Pharmacol 47:1112-1118

Seasholtz AF, Thompson RC, Douglass JO (1988): Identification of a cyclic adenosine monophosphate-responsive element in the rat corticotropin-releasing hormone gene. Mol Endocrinol 2:1311-1319

Seckl JR (1997): 11ß-Hydroxysteroid dehydrogenase in the brain: A neural regulator of glucocorticoid action? Front Neuroendocrinol 18:49-99

Seckl JR, Fink G (1992): Antidepressants increase glucocorticoid and mineralocorticoid receptor mRNA expression in rat hippocampus in vivo. Neuroendocrinology 55:621-626

Seckl JR, Dickson KL, Yates C, Fink G (1991): Distribution of glucocorticoid and mineralocorticoid receptor messenger RNA expression in human postmortem hippocampus. Brain Res 561:332-337

Sheline YI, Wang PW, Gado MH, Hsernansky JG, Vannier MW (1996): Hippocampal atrophy in recurrent major depression. Proc Natl Acad Sci USA 93:3908-3913

Sheline YI, Gado M, Price JL (1998): Amygdala core nuclei volumes are decreased in recurrent major depression. NeuroReport 9:2023-2028

Sheline YI, Sanghavi M, Mintun MA, Gado MH (1999): Depression duration but not age predicts hippocampal volume loss in medically healthy women with recurrent major depression. J Neurosci 19:5034-5043

Shelton RC, Manier DH, Peterson CS, Truitt CE, Sulser F (1999): Cyclic AMP-dependent protein kinase in subtypes of major depression and normal volunteers. Intl J Neuropsychopharmacol 2:187-192

Shibata H, Spencer TE, Onate SA, Jenster G, Tsai SY, Tsai M-J, O'Malley BW (1997): Role of co-activators and corepressors in the mechanism of steroid/thyroid receptor action. Rec Progr Hormone Res 52:141-163

Sillaber I, Montkowski A, Landgraf R, Barden N, Holsboer F, Spanagel R (1998): Enhanced morphine-induced behavioural effects and dopamine release in the nucleus accumbens in a transgenic mouse model of impaired glucocorticoid (type II) receptor function: Influence of long-term treatment with the antidepressant moclobemide. Neuroscience 85:415-425

Siuciak JA, Lewis D, Wiegand SJ, Lindsay RM (1996): Antidepressant-like effect of brain-derived neurotrophic factor. Pharmacol Biochem Behav 56:131-137

Skutella T, Probst JC, Renner R, Holsboer F, Behl C (1998): Corticotropin-releasing hormone receptor (type I) antisense targeting reduces anxiety. Neuroscience 85:795-805

Smith GW, Aubry J-M, Dellu F, Contarino A, Bilezikjian LM, Gold LH, Hauser C, Bentley CA, Sawchenko PE, Koob GF, Vale W, Lee K-F (1998): Corticotropin-releasing factor receptor 1-deficient mice display decreased anxiety, impaired stress response, and aberrant neuroendocrine development. Neuron 20:1093-1103

Sonntag A, Rothe B, Guldner J, Yassouridis A, Holsboer F, 
Steiger A (1996): Trimipramine and imipramine exert different effects on the sleep EEG and on nocturnal hormone secretion during treatment of major depression. Depression 4:1-13

Spanagel R, Stöhr T, Barden N, Holsboer F (1996): Morphineinduced locomotor and neurochemical stimulation is enhanced in transgenic mice with impaired glucocorticoid receptor function. J Neuroendocrinol 8:93-97

Spencer RL, Kim PJ, Kalman BA, Cole MA (1998): Evidence for mineralocorticoid receptor facilitation of glucocorticoid receptor-dependent regulation of hypothalamic-pituitary-adrenal axis activity. Endocrinology 139:2718-2726

Spencer TE, Jenster G, Burcin MM, Allis CD, Zhou J, Mizzen CA, McKenna NJ, Onate SA, Tsai SY, Tsai M-J, O'Malley BW (1997): Steroid receptor coactivator-1 is a histone acetyltransferase. Nature 389:194-198

Spengler D, Rupprecht R, Phi Van L, Holsboer F (1992): Identification and characterization of a $3^{\prime}, 5^{\prime}$-cyclic adenosine monophosphate-responsive element in the human corticotropin-releasing hormone gene promoter. Mol Endocrinol 6:1931-1941

Stalla GK, Stalla J, von Werder K (1989): Nitroimidazole derivates inhibit anterior pituitary cell function apparently by a direct effect on the catalytic subunit of the adenylate cyclase holoenzyme. Endocrinology 155:699_ 706

Stec I, Barden N, Reul JMHM, Holsboer F (1994): Dexamethasone nonsuppression in transgenic mice expressing antisense RNA to the glucocorticoid receptor. J Psychiatric Res 28:1-5

Steckler T, Weis C, Sauvage M, Mederer A, Holsboer F (1999): Disrupted allocentric but preserved egocentric spatial learning in transgenic mice with impaired glucocorticoid receptor function. Behav Brain Res 100:77-89

Steckler T, Sauvage M, Holsboer F (2000a): Glucocorticoid receptor impairment enhances impulsive responding in transgenic mice performing on a simultaneous visual discrimination task. Eur J Neuroscience, In press

Steckler T, Rammes G, Sauvage M, van Gaalen MM, Weis C, Zieglgänsberger W, Holsboer F (2000b): Effects of the monoamine oxidase A inhibitor moclobemide on hippocampal plasticity in GR-impaired transgenic mice. J Psychiatric Res, In press

Stenzel-Poore MP, Heinrichs SC, Rivest S, Koob GF, Vale WW (1994): Overproduction of corticotropin-releasing factor in transgenic mice: A genetic model of anxiogenic behavior. J Neurosci 14:2579-2584

Stoecklin E, Wissler M, Gouilleux F, Groner B (1996): Functional interactions between Stat 5 and the glucocorticoid receptor. Nature 383:726-728

Stoecklin E, Wissler M, Moriggl R, Groner B (1997): Specific DNA binding of Stat5, but not of glucocorticoid receptor, is required for their functional co-operation in the regulation of gene transcription. Mol Cell Biol 17:6708-6716

Ströhle A, Poettig M, Barden N, Holsboer F, Montkowski A (1998): Age- and stimulus-dependent changes in anxiety-related behaviour of transgenic mice with GR dysfunction. NeuroReport 9:2099-2102

Ströhle A, Pasini A, Romeo E, Hermann B, Spalletta G, di Michele F, Holsboer F, Rupprecht R (2000): Fluoxetine decreases concentrations of $3 \alpha, 5 \alpha$-tetrahydrodeoxycor- ticosterone (THDOC) in major depression. J Psychiatric Res 34:183-186

Swanson LW, Simmons DM (1989): Differential steroid hormones and neural influences on peptide mRNA levels in CRH cells of the paraventricular nucleus: A hybridization histochemical study in the rat. J Comp Neurol 285:413-435

Thakore JH, Dinan TG (1995): Cortisol synthesis inhibition: A new treatment strategy for the clinical and endocrine manifestations of depression. Biol Psychiatry 37:364-368

Timpl P, Spanagel R, Sillaber I, Kresse A, Reul JMHM, Stalla GK, Blanquet V, Steckler T, Holsboer F, Wurst W (1998): Impaired stress response and reduced anxiety in mice lacking a functional corticotropin-releasing hormone receptor 1. Nature Genet 19:162-166

Trapp T, Rupprecht R, Castrèn M, Reul JMHM, Holsboer F (1994): Heterodimerization between mineralocorticoid and glucocorticoid receptor: A new principle of glucocorticoid action in the CNS. Neuron 13:1457-1462

Trapp T, Holsboer F (1996a): Heterodimerization between mineralocorticoid and glucocorticoid receptor increases the functional diversity of corticosteroid action. Trends in Pharmacol Sci 17:145-149

Trapp T, Holsboer F (1996b): Nuclear orphan receptor as a repressor of glucocorticoid receptor transcriptional activity. J Biol Chem 271:9879-9882

Tronche R, Kellendonk C, Kretz O, Gass P, Anlag K, Orban PC, Bock R, Klein R, Schütz G (1999): Disruption of the glucocorticoid receptor gene in the nervous system results in reduced anxiety. Nature Genet 23:99-103

Uhr M, Steckler T, Yassouridis A, Holsboer F (2000): Penetration of amitriptyline, but not fluoxetine, into brain is enhanced in mice with blood-brain barrier deficiency due to mdr1a P-glycoprotein gene disruption. Neuropsychopharmacology 22:380-387

Uzunova V, Sheline Y, Davis JM, Rasmusson A, Uzunov DP, Costa E, Guidotti A (1998): Increase in the cerebrospinal fluid content of neurosteroids in patients with unipolar major depression who are receiving fluoxetine or fluvoxamine. Proc Natl Acad Sci USA 95:3239-3244

Vale W, Spiess J, Rivier C, Rivier J (1981): Characterization of a 41-residue ovine hypothalamic peptide that stimulates secretion of corticotropin and $\beta$-endorphin. Science 213:1394-1397

van der Burg B, Liden J, Okret S, Delaunay F, Wissink S, van der Saag PT, Gustafsson J-A (1997): Nuclear factor-кB repression in antiinflammation and immunosuppression by glucocorticoids. Trends Endocrinol Metab $8: 152-157$

van Haarst AD, Welberg LAM, Sutanto W, Oitzl MS, De Kloet ER (1996a): 11 $\beta$-Hydroxysteroid dehydroxygenase activity in the hippocampus: Implications for in vivo corticosterone receptor binding and cell nuclear retention. J Neuroendocrinol 8:595-600

van Haarst AD, Oitzl MS, Workel JO, De Kloet ER (1996b): Chronic brain glucocorticoid receptor blockade enhances the rise in circadian and stress-induced pituitary-adrenal activity. Endocrinology 137:4935-4943

von Bardeleben U, Holsboer F (1989): Cortisol response to a combined dexamethasone-hCRH challenge in patients with depression. J Neuroendocrinol 1:485-488 
von Bardeleben U, Holsboer F (1991): Effect of age upon the cortisol response to human CRH in depressed patients pretreated with dexamethasone. Biol Psychiatry 29: 1042-1050

von Bardeleben U, Holsboer F, Stalla GK, Müller OA (1985): Combined administration of human corticotropinreleasing factor and lysine vasopressin induces cortisol escape from dexamethasone suppression in healthy subjects. Life Sci 37:1613-1619

Watanabe Y, Gould E, McEwen BS (1992): Stress induces atrophy of spatial dendrites of hippocampal CA3 pyramidal neurons. Brain Res 588:341-345

Weninger SC, Dunn AJ, Muglia LJ, Dikkes P, Miczek KA, Swiergiel AH, Berridge CW, Majzoub JA (1999): Stressinduced behaviors require the corticotropin-releasing hormone (CRH) receptor, but not CRH. Proc Natl Acad Sci USA 96:8283-8288

Wissink S, van Heerde EC, van der Burg B, van der Saag PT (1998): A dual mechanism mediates repression of NF-кB activity by glucocorticoids. Mol Endocrinol 12:355-363
Wolkowitz OM, Reus VI, Chan T, Manfredi F, Raum W, Johnson R, Canick J (1999): Antiglucocorticoid treatment of depression: Double-blind ketoconazole. Biol Psychiatry 45:1070-1074

Young EA, Lopez JF, Murphy-Weinberg V, Watson SJ, Akil H (1998): The role of mineralocorticoid receptors in hypothalamic-pituitary-adrenal axis regulation in humans. J Clin Endocrinol Metab 83:3339-3345

Zeiner M, Niyaz Y, Gehring U (1999): The hsp70-associating protein Hap46 binds to DNA and stimulates transcription. Proc Natl Acad Sci USA 96:10194-10199

Zobel AW, Yassouridis A, Frieboes R-M, Holsboer F (1999): Cortisol response to the combined dexamethasone$\mathrm{CRH}$ test predicts medium-term outcome in patients with remitted depression. Am J Psychiatry 156:949-951

Zobel AW, Nickel T, Künzel HE, Ackl N, Sonntag A, Ising M, Holsboer F (2000): Effects of the high-affinity corticotropin-releasing hormone receptor 1 antagonist R121919 in major depression: The first 20 patients treated. J Psychiatric Res, 34:171-181 